\title{
Covid-19 Pandemisi Gölgesinde Sosyo-Mekânsal Eşitsizlikler ve Kent Planlama: Diyarbakır Örneği
}

\author{
Esra Karadaş ${ }^{1}$ \\ ORCID: 0000-0003-0415-4464
}

\author{
İsmail Ekinci 2 \\ ORCID: 0000-0002-1434-6593
}

Öz

Bu çalı̧̧ma, Covid-19 pandemisi sürecinde, Diyarbakır kent planlamasına odaklanarak; neoliberal politikalarla dönüşen kent mekânmı, pandemi ve gündelik yaşam arasındaki ilişkiyi ele alarak incelemeyi hedeflemektedir. Analiz çerçevesine kent mekânn ve kamusal alanları alan çalışma, Diyarbakır'n neoliberal süreçte ekonomik ve mekânsal olarak eşitsiz geliştiği ön kabulüyle, pandemi sürecinde bireylerin sahip olduğu maddi koşullarm önemine odaklanmaktadır. Bu durumun mekânsal yansiması olarak güvenlikli siteler gibi kamusal alandan belli sinırlar ve mekanizmalarla ayrllan konutlar ile gündelik yaşam pratikleri arasındaki ilişki, pandeminin sınıssal koşullar üzerinden nasıl deneyimlendiğine dair bilgi vermektedir. Metodolojik olarak bu çalışma, tarihsel bir perspektifte kentin mekânsal örgütlenmesini ve bunun salgın süreci ile ilişkisini, kent üzerine yapılmış araştırma verilerine dayanarak argümanıı oluşturmaktadır. Çalı̧̧mamız, 1999'lardan sonra imara açılan Kayapınar ilçesi ile genellikle iş̧̧i sınıfinın yaşadığı, gecekondulaşma eğiliminin yoğun olduğu ve kentin en eski ilçelerinden biri olan Bă̆lar ilçesi arasindaki sosyo-kültürel ve mekânsal farklılaşmayı pandemi bağlamında ele alacaktır.

Anahtar Kelimeler: Covid-19, Güvenlikli siteler, Diyarbakır, Pandemi, Kayaptnar ve Bağlar.

\footnotetext{
${ }^{1}$ Doktora Öğrencisi, Ankara Üniversitesi, E-mail: karadassesr@gmail.com

${ }^{2}$ Yüksek Lisans Öğrencisi, İstanbul Üniversitesi, E-mail: ziryap@gmail.com idealkent (c) Kent Araştırmaları Dergisi (Journal of Urban Studies) 


\title{
Socio-Spatial Inequalities and City Planning in the Shadow of the Covid-19 Pandemic: The Case of Diyarbakir
}

\author{
Esra Karadaş ${ }^{3}$ \\ ORCID: 0000-0003-0415-4464
}

İsmail Ekinci ${ }^{4}$

ORCID: 0000-0002-1434-6593

\begin{abstract}
This study focuses on Diyarbakir city planning during the Covid-19 pandemic process; It examines the relationship between urban space, the pandemic, and daily life experiences that are transformed by neoliberal policies. By taking urban and public spaces into the analyzing framework, this study focuses on the importance of the material conditions during the pandemic process, with the presupposition that Diyarbakir has been developed unevenly economic-wise and spatial-wise in the neoliberal process. As a spatial reflection of this situation, the relationship between residences is separated from the public space by certain borders and mechanisms, such as gated communities and daily life practices, which provides information on how the pandemic is experienced through class conditions. Methodologically, this study forms its argument on the spatial organization of the city in a historical perspective and its relationship with the epidemic process, based on research data on the city. It will deal with the differentiation between Kayapinar district, which was opened for construction after the 1999s, and Baglar district, one of the city's oldest districts, where primarily working-class people live, and the tendency of slums is intense.
\end{abstract}

Keywords: Covid-19, Gated Communities, Diyarbakır, Pandemics, Kayapinar and Baglar.

\footnotetext{
${ }^{3}$ Phd Student, Ankara University, E-mail: karadassesr@gmail.com

${ }^{4}$ Graduate Student, İstanbul University, E-mail: ziryap@gmail.com

idealkent $\odot$ Kent Araştırmaları Dergisi (Journal of Urban Studies) http://idealkentdergisi.com
}

Geliş Tarihi Received Date: 20.02.20201 Kabul Tarihi Accepted Date: 28.12.2021 


\section{Giriş}

19. yy. ortalarmda III. Napolyon tarafindan Paris'in imarn için görevlendirilen Baron Haussmann'm ortaya koyduğu modelin esasin da mahalle ve semtlerin ekonomik açıdan türdeşleştirilmesi, yani toplumsal sinıflarm birbirinden yahtılması oluşturuyordu. Çünkü; kent merkezinde işçi ve yoksullarn oturdukları konutlar hem rahatsı edici hem de kentin diğger kesimleri için özellikle salgın hastalk tehdidiyle birer "bela merkezi" olarak görülüyordu. (Kaygalak, 2008, s.43)

Kaygalak'ın salgın hastalıklar bağlamında, bir "bela merkezi”' olarak tanımladığı kentler, Covid-19 pandemi sürecinde de benzer bir duruma sahne olmuştur. Modern kent planlama ve sosyal bütünlügü̈nü etkileyen salgın hastalıklar; bu süreçte de aslında kentlerde var olan keskin ayrışmanın daha derinleşmesini sağlamış ve bu durumu gözle görünür bir netliğe kavuşturmuştur. Bu izlekte bakıldığında, pandemi sürecinin en kritik anlarında gündemi meşgul eden konular, temelde bu eşitsizliğe dayanan tartışmalard1..$^{5}$ Bu tartışmalar arasında özellikle toplumun belirli kesimlerinin sağlık hizmetlerine erişmekte yaşadığı sorunlar ve özelleştirilen temel kamusal hizmetlerin (sağlık, ulaşım, barınma ve eğitim) yarattı̆̆ı uçurumlar epey tartışıldı. Meydana gelen bu problemlere ilişkin Dünya Sağlık Örgütü (WHO) tarafından, 1970'li yıllardan beri sağlık hizmetlerine erişim, sosyal adalet ve salgın hastalıkların yakın ilişkisine dair önemli ipuçları sunan "Herkes için Sağlık" gibi önemli stratejiler ve çalışmalar gerçekleştirilmiştir. Bu konudaki, bir diğger önemli katkı da Barton ve Grant (2006) tarafından geliştirilen "Sağlık Haritası" çalışmasıdır. Bu haritaya göre, sağhlklı olma ve bireyler için să̆hlk; küresel ekosistem, doğal çevre, yapılı çevre, faaliyetler, yerel ekonomi, topluluk, yaşam tarzı ve halk olarak birbirini tamamlayan bir zincirin parçalarıdır. Dolayısıyla, bu dinamiklerden biri bile eksik ya da sübjektif olursa sağlıklı olma durumu -bireysel olarak iddia edildiğinin aksine- toplumsal bir problem haline gelmektedir. Barton ve Grant tarafindan vurgulandığı üzere, yapılı çevre ve kent planlama stratejileri, Dünya

\footnotetext{
${ }^{5}$ Benzer çalışmalar için bknz:

Heinrich Böll Stiftung Derneği. (2020). Pandemi Döneminde Derin Yoksulluk ve Haklara Erişim Araştırması.

Enstitü İstanbul. (2020). “Yeni Normal” Süreci Raporu: Öngörüler, Politikalar ve Öneriler Rehberi.

Enstitü İstanbul. (2021). Salgında Kent Yoksulluğu: İstanbul'da Yoksulluk Profilleri. Enstitü İstanbul. (2020). COVID-19 Pandemisinin İstanbul Ekonomisine Etkileri.
} 
Sağlık Örgütü'nün "Herkes için Sağlık” hedefi ile de yakından ilişkilidir. Bu durumla ilişkili olarak, son dönemde Dünya Doğayı Koruma Vakfı (WWF) tarafindan yayınlanan “Doğanın Yok Oluşu ve Pandemilerin Yükselişi” başlıklı rapor da "insanın, ekosistemler ve biyolojik çeşitlilik üzerindeki etkileri ile bazı hastalıkların yayılması arasındaki bağlantılara" dikkat çekilmiştir (2020, s.3).

Bütün bunların aksine, neoliberal dönemde yaşanan pandemi sürecinde, sermaye merkezli politikaların sürdürülmesi, ülkelerin salgın riskine karşı ilk aşamada önlem almamalarına ve metropollerdeki yüksek ölüm vakalarına neden oldu. Bu süreçte, Covid-19'a karşı hükümetler tarafindan alınan önlemler, öncelikli olarak ekonomik krizin derinleşmemesini amaçlamaktaydı. Dolayısıyla, COVID19'un etkisi, "zaten var olan, ancak şimdi büyük ölçüde büyütülmüş olan sağllk eşitsizliği ile gelir eşitsizliğinin birleştirilmesi" olarak tanmlanabilir (Przeworski, 2020). Yaşadığımız pandemi sürecinde, "Evde Kal”, "Sosyal Mesafe" ve "Hayat Eve Sığar" gibi söylemlerle, önleyici tedbirlerin bireysel yükümlülükle bağdaştırılması öne çıkmaktadır. Pandemi koşullarında toplum sağlı̆̆ı açısından tali sayılabilecek işler, kapitalist kâr için asli olmaya devam etmiştir. Bu anlamıla, işçi sınıfını üretime çağran iktidar(lar), toplumun üst ve orta sinufina "Evde Kal" diyerek, neoliberal bir söylem geliştirmiştir. ${ }^{6}$ Pandemi sürecinde, küresel olarak bu türden önleyici tedbirlerin alınması, gündelik pratikte pandeminin hem mekânsal olarak hem de sosyo-ekonomik olarak, sınıf temelli deneyimlenmesine sebep olmaktadır. Dolayısıyla, bu durum hem geçmişteki pandemi deneyimlerinde hem de günümüz pandemisinde enfekte riskinin, toplumun savunmasiz ve güvencesiz kesimlerinde daha yoğun olarak görülmesine neden olmuştur. Dolayısıyla, "bulaşıcı hastalkklar karşısında toplum, mekânsal bünyesindeki en zayıf halkalarm (mülteciler, göçmenler, yoksul ve yoksunlar, tehlikeli mahallerde riskli işlerde çalışmaya mecbur kalanlar, yaşllar, sakatlar, yoksun kronik hastalar, erişim imkanlarnndan mahrum bırakılmış kadmlar ve çocuklar gibi.) sağhlğa erişebildiği ölçüde korunabilir" (Odman ve Tülek, 2020, s.512). Modern ve neoliberal şehircilikle birlikte, kentsel ve kamusal mekanların mutenalaştırılması, sermayedar ve üst-orta sınıf kesimin maddi koşullarına uygun olarak geliştirilmesi ve kent yoksullarına terk edilen kentsel alanların etkileri, pandemi sürecini doğrudan etkilemiştir.

\footnotetext{
${ }^{6}$ İlgili söylem bağlamında resmî kurumlarca gönderilen genelge ve ilgili haberler için bknz: İçişleri Bakanlığı. (2021). 81 İl Valiliğine Tam Kapanma Tedbirleri Genelgesi.

Evrensel Gazetesi (2021). Vaka Sayılarının Yükseldiği Adana'daki İşçiler: Bize Öleceksen Öl Deniliyor.

BBC Türkiye. (2020). Sokağa Çıkma Yasağında Çalışan İşçiler: Bizim Sağlığımız Önemli Değil Mi, Biz Ölmez Miyiz?

Sendikaorg (2021). Pandemide Çalışmak Zorunda Olmak: İşçi Sağlığı Yoksa, Halk Sağlığı Da Yok.
} 
Söz konusu bağlamda, Diyarbakır ölçeğinde de pandemi deneyiminin mekânsal olarak keskin ve net bir biçimde görülmesi; buna ek olarak, neoliberalleşen bir şehir olarak Diyarbakır' ın literatürde diğer kentlere kıyasla daha az ele alınması, çalışmanın önemini ve motivasyonunu oluşturan temel dinamiklerdir. Tarihsel olarak bakıldığında da Diyarbakır kent tarihinde daha önce yaşanan Veba, Kolera ve Veba-i Bakarî salginları sebebiyle, bir "bela merkezi" olduğu bilinmektedir (Bozan, 2015, s. 220-240; Mengirkaon, 2018). Hatta bu nedenle, 1932 yıllinda Vali Faiz Ergun tarafindan, "salgın hastalıklara ve havasızlığa bir çözüm" olarak, kent surlarının bomba ile yıkılması istemiyle çalışmalara teşebbüs edilmiştir. Bu durum, söz konusu dönemde, bölgede saha çalışmasında olan Albert Gabriel'in yazdığı rapor sayesinde durdurulmuştur. ${ }^{7}$ Dolayısıyla, Diyarbakır'da modern kent planlama ile salgın hastalıkların ilişkisi daha eskiye, kent tarihinin erken cumhuriyet dönemlerine kadar dayanmaktadır.

Bu doğrultuda yapılacak inceleme ile hem salgin hastalık ve modern kent planlama ilişkisine değinilecek hem de homojen olarak inşa edilen kentsel alanların, salgın deneyimleme biçimine etki kapasitesi değerlendirilecektir. Böylelikle, neoliberal şehirciliğin etki ettiği yeni kentsel alanlarda yaşanan ekonomik, sosyolojik ve politik eşitsizliğe Diyarbakır örneği üzerinden bir perspektif sağlanacaktır. Bu çerçeveyle, çalışma özellikle sınıfsal ayrışma ve salgın deneyimi dinamikleri olguları üzerinden kentsel çalışmalar literatürüne katkı sunmayı amaçlamaktadır. Salgin ve kent ilişkisi analiz edilirken Le Haussmann etkisi ve Corbusier' in Radiant City projesi ile Kayapınar'da yoğun olarak inşa edilen güvenlikli sitelerin benzerliği de analiz edilecektir.

\section{Kapitalizm ve Modern Kent Planlama İlişkisi}

Kent çalışmaları literatürünün açıkça gösterdiği gibi, kent mekânının form kazanmasın etkileyen en önemli dinamiklerden biri de salgın hastalıklardır. Özellikle, kentin büyüme şeklini ve ölçeğini keskin bir biçimde dönüştüren salgin hastalıklar, kent gelişimindeki ve modern kent planlamadaki en önemli faktörlerden biri olagelmiştir. Özellikle 19. yüzyıl sonlarında kurumsallaşan modern kent planlama; Sanayi Devrimi sonrasında, kentlerde yaşanan yoğunluğu örgütlemeye ve düzenlemeye yönelik geliştirilmiştir (Ersoy, 2005; Tekeli, 2011). Tekeli (2011), "modern kent planlamanın özellikle 1848 Devrimi sonrasında İngiltere, Almanya ve Fransa'da toplumsal düzenin korunması ve kentsel alanların düzenlenmesi için

\footnotetext{
${ }^{7}$ Detaylar için bknz:

Değertekin, H. (1999). Diyarbakır Surlarının Bugünkü Durumu, Diyarbakır Müze Şehir, YKY, İstanbul: 179-193.
} 
itici dinamik olduğunu” belirtmektedir (2011, s.31). Tekeli'nin belirttiği üzere, “Kolera salgınları nedeniyle, İngiltere'de sağlık yasalarının öncülüğünde çalışmalar başlamışken, Paris'te de Haussmann operasyonlara başlamıştı" (2020, s.33). Bu dönemde, kent planlamanın yönetim mekanizmaları için sağladığı avantajlar, özellikle Paris örneğinde dikkat çekicidir. Bu açıdan, Baron Haussmann tarafindan geliştirilen proje politik bir muhtevaya sahiptir. Bu planlama hem sıhhileştirme çalışmaları hem de yükselen burjuvazi için kentsel fursatlar ve kentsel alanlar anlamına gelmekteydi (Chapman, 1953; Tekeli, 2011). Dolayısiyla, bu dönemde devlet tekelinde gerçekleştirilen planlama formunda, kent seçkinlerine ve burjuvaziye özel bir alan açldığı görülmektedir. Bu durumun somut bir örneğini, Nuran Yıldırım çalışmasında şu şekilde aktarmaktadır: "Paris'teki, ilk kolera salgınında halk, ölümlerin koleradan ileri geldiğine inanmamış, "devlet fakirlerden kurtulmak için onları zehirleyerek yok etmeye çalışıyor" diyerek isyan etmişti (Yıldırım, 2006, s.2). Görüldüğü gibi, yeni yeni kurumsallaşan modern kent planlamanın sınıfsal ve politik karakteri, ilk aşamalarında dahi salgın hastalıkların kent ölçeğinde eşitsiz görülmesine ve sınıfsal grupların mekânsal olarak ayrıştırılmasına neden olmuştur. Bu duruma benzer olarak, geçmişte yaşanan Kolera salgınları ve kent mekânının örgütlenme biçiminde hijyenin etkisi gösterilebilinir. (Alessandro, Apolloni ve Capasso, 2017). Ayrica, söz konusu sorunun Engels'in Konut Sorunu çalışmasında da yer bulduğu görülmektedir. Engels, modern kent planlamanın ilk örneklerinden biri olan Paris örneğini, "hile ve bireysel zenginleşme amaciyla yapıldığını ve artık Haussmann'ın ruhunun yurt dışına taştı̆ını" vurgulamaktadır (Engels, 2013, s.21) Engels, modern kent planlamadan sonra, konut formunun uğradığı değişikliği "işçilerimizi her gece içine kapattı̆ı hastalıkların üreme yeri, delik deşik bodrumlar ortadan kaldırılmamıştır, başka yere kaydırılmıştır" olarak eleştirmiş ve kent yoksulları için konut şartlarının iyileştirilmesini amaçlamaktan ziyade, yerinin değiştirmekle yetindiğini vurgulamıştır (2013, s.82). Kırdan kente yoğun olarak yaşanan göçler ve kentte yığılmadan dolayı meydana gelen hastalıklar, altyapı-ulaşım sorunları, konut sıkıntısı ve çevre problemlerine bir yanıt olarak geliştirilen kent planlama; yapılı çevreüretme stratejilerindeönemli bir metot olarak kullanılmış vekent planlamayla birlikte, sınıfsal ayrışma böylece mekânsal ölçekte görünür olmaya başlamıştır.

Salgınlarla ilişkili olarak, kent planlamanın uygulanmasının ilk örneğini gördügü̈müz Haussmann uygulamaları, kentsel alanların mutenalaştırılmasının yayginlaştrilmasında temel teşkil etmiştir. Seçkin Bölge Kanunu ile söz konusu alanın yoksullardan arındırılarak yeniden inşa edilmesi ve daha sonra daha yüksek ücretlerle kentin seçkinlerine satılması, günümüzün kapitalist kentleşme biçiminin temeli olarak görülebilmektedir. Lefebvre, Paris örneği üzerinden, Haussmann'1 
“Toplumu utanmadan iktidar mücadelelerinin -sadece kozu değil- ganimeti haline getirmek için toplumun üzerine çkan bu Bonapartist devletin adamı olan Baron Haussmann, engebeli ama canlı sokakların yerine uzun caddeler, iğrenç ama hareketli mahallelerin yerine burjuvalaşmış semtler koymaktadır" (Lefebvre, 2018, s.33-34) diyerek eleştirmektedir. Ayrıca, Tekeli, Haussmann'ın bu ikonik projesinin, Le Corbusier'e de ilham vermiş olabileceğini vurgulamaktadır (2011, s.33). Mumford tarafindan da teknolojiye ve bilime tapmasiyla, "elitist bir teknokrat ve yeni endüstriyel uygarlı̆ga olan yakınlığıla" eleştirilen Le Corbusier (Fitting, 2002, s.74), genellikle uyguladığı rasyonel ve planlı yapıların insan doğasına uzak yapısı ve yabanclaştırıc etkisi nedeniyle, literatürdeki çoğu kişi tarafindan reddedilmiştir. Jacobs, "şehir karşıtı planlamanın doğrudan adaletsizliğin mahallelerine nasıl getirileceğine dair en dramatik fikre sahip adam" olarak Le Corbusier'i tanımlamaktadır (Jacobs, 1961, s.21). Buna ek olarak, “Percival vePaul Goodman, Lewis Mumford, ve Peter Hall gibi isimler de insan doğasının derin bir yanlış anlaşılmasına dayalı şehir planlama anlayışını da reddetmektedir (Fitting, 2002). Modern mimarinin kınamasını paylaşan bu eleştiriler, bu tür planlı şehirlerdeki yaşamın yabanclaştııı etkilerine ve özellikle Le Corbusier'in "dikey yoğunluk" kavramından kaynaklanan sokak yaşamının yokluğuna odaklanmaktadır" (Fitting, 2002, s.80).

Kentin rasyonel ve geometrik biçimde, Le Corbusier' in Radiant City projesindeki gibi planlanması kentte çok büyük ve hayati olan değişimleri de beraberinde getirmektedir. Bu değişimin temel nedeni, projenin sadece bir yapılı çevre sunması değil, yeni bir toplumsallaşma biçimini dayatmasıdır. Radikal, sınırlayıc ve totaliter bir arka plana sahip bu proje, yoğun nüfusa sahip gökdelenler üzerinden, kamusal alanı kesintiye uğratmaktadır. Le Corbusier, rasyonel bir bağlama oturttuğu modern kent planlama sayesinde "yapılacak savaşın hangi yönde yapılacağına karar verebilme" imkanının doğruluğunu açıklamaktadır (Corbusier, 1929, s. 22). Dolayısıyla, modern kent planlama kurallarının zorunluluğunun vurgular. Ayrıca, Le Corbusier, "bu modern kent planlamanın tehlikelibir futürizm olmadığını, mimarlık tarafından düzenlenen bir gösteri olduğunu" açıklar (Corbusier,1929, s.29).

Modern kent planlamanın sahip olduğu bu arka plan, küresel olarak kentlerin rasyonel bir biçimde planlanmasının önünü açmıştır. Dolayısıyla, bu durumla beraber çok önemli bir problem ortaya çıkmaktadır: şehir hakkı. Tam bu noktada şu sorunun sorulması elzemdir; kapitalist rasyonel bir verimlilik bağlaminda gelişen planlama formu, kent yoksulları, işçi sınıfı ve azınlık gruplar için nasıl bir deneyimi beraberinde getirmektedir? Castell bu durumu, "kapitalizmde içsel olarak var olan geleneksel eşitsizliğin, konut koşullarından çalısma saatlerine kadar uzanan ve sağlık, eğitim ve kültürel imkanları da içerdiğine" değinmektedir (Castell, 2017, 
s.34). Ayrıca, Harvey de bu durumu, "sermaye birikimi, coğrafi genişleme, mekândan yeniden düzenleme ve coğrafi eşitsiz gelişim olmadan kapitalizm sürdürülebilir olamazdı" şeklinde açklamaktadır (Harvey,2015, s.448). Harvey'in özellikle belirttiği "sermaye ve kapitalist ilişkiler içinde kent matris ve rasyonel peyzaj kesintisiz değişime uğramaktadır" söylemi de yine bu durumun önemini vurgulamaktadır (Harvey,2016, s.43). Dolayısıyla, Haussmann ve Le Corbusier'de gördüğümüz örnekler, kapitalist üretim ilişkilerinin ve yapılı çevre üretiminin uyumlu bir ittifakı olarak görülmelidir. Bu planlama ile, sınıfsal ayrışmalar mekânsal ölçekte bir kez daha somut olarak görünür olmaktadır.

Sermaye egemenliğinin kentsel mekânda tesis edilmesi, şehrin merkezi bölgelerinde soylulaştırılması veya yeni alanların ranta açılmasının zemini olmuştur. $\mathrm{Bu}$ ayrıca sermaye nezdinde yeni birikim yollarının oluşmasını sağlamıştır. Yeni tip konut formları kendini göstermiş, bu yaşam alanları orta üst sınıflara yönelik geliştirilirken, diğer toplumsal sınıfların bu alanlardan dışlanmasına sebep olmuştur. Sonuç olarak, küresel ölçekte kentlerde yaşanan bu yoğunlaşma, kent içinde gerek planlarla gerekse ihtiyaçlar doğrultusunda bir yönelimi getirmektedir. Sosyal donatı ve yeşil alanların yoğun olduğu alanlar ile kent merkezindeki yoğunluklu alanlar -ki daha çok bu alanlarda kent yoksulları barınmaya başlamıştır- düşünüldüğünde mekânsal olarak bir ayrışma yaşanmıştır. Çünkü, yeni yapılaşan yerleşim alanları orta-üst sınıfin mekânı haline gelirken, var olan ve eskiyen yerleşim yerleri ise kent yoksullarına bırakılmıştır. Kentsel yaşamın bu biçimi ile mekânsal olarak organize edilmesi, modern kent planlamanın özünü oluştura gelmiştir.

\section{Salgin ve Kent Mekânı}

Pandemi ve kent mekânı arasındaki ilişkiyi incelediğimiz bu çalışma, geniş bir literatüre dayanmaktadır. Özellikle, hastalıkların sınırlandırılması ve bundan dolayı yaşanan yapılı çevrenin ayrıştırılması gibi durumlara ilişkin birçok çalışma mevcuttur. Birçok çalışmanın konusu olan, salgın hastalıkların sınıfsal karakteri sadece günümüz için değil, daha önce yaşanan salgın hastalıklar için de geçerlidir. Kolera salgını için konuşan Kenneth T. Jackson, "salgına verilen ilk tepkinin şehrin sınıf, ırk ve din ayrımlarını her zamankinden daha fazla açığa çıkardığını ve hastalığın alt sınıfların veya "dışlanmışların” olduğu mahallelerde, özellikle Afrikalı-Amerikalılar' ın ve göçmen İrlandalı Katoliklerin "sefalet ve pis kokularla" dolu olduğu Five Points olarak bilinen gecekondu mahallelerinde en çok etkilendiğini" ifade etmişti (Wilford, 2008). Kolera salgınında, enfeksiyonun kirli sudan dolayı bulaştığının belir- 
lenmesi ve daha sonra modern kent planlamanın bulaşma riskini en aza indirgeyerek kenti mutenalaştırması, söz konusu durumu kanıtlar niteliktedir. Hatta halen su depoları ve su kanallarının yoksul mahallelere yakın olarak planlanması, kirli suyun yine aynı şekilde planlamaya yerleştirilmesi, geçmişte yaşanan bu hastalıkların bir mirası olarak okunabilmektedir.

Salgın özelinde, Hoffman (2016) da bu durumu Ebola salgınını kent planlama ile incelediği çalışmasında, "aşı ya da ilacın bulunmadığı durumlarda fiziksel karantinanın ve ayrışmanın işlevselliğini" cordons sanitaires örneğiyle açılamıştır. Başka bir örnek olan Tüberküloz'da da yetersiz beslenen ve sanayileşmenin hızıyla kalabalık koşullarda çalışan kentli işçi sınıfı ile yakından ilişkili olduğu belirtilmektedir (Campell,2005). Dolayısıyla, salgın hastalıkların kent planlamada sinıfsal karakterli olduğunu her dönemde görmekteyiz. Tarihsel olarak bakıldığında en önemli örneklerden biri belki de Dr. John Snow'un (1857) veri mekansallaştırma yöntemi ile Kolera salgınına dair çı̆̆ır açıcı çalışmasıdır (Kıygı, 2020). Bu çalışmada da haritalar üzerinden benzer bir yöntem takip edilerek hastalığın mekânsal düzlemi üzerinden çıkarımlar yapılmaktadır. Dr. John Snow vaka yerlerini tespit ederek, Kolera'nın su yoluyla bulaştığını kanıtlamıştır. Dolayısıyla, dönemin kent planlama çalışmaları da kirli sudan uzakta, hijyen oranının ve havalandırma imkanını daha yüksek olduğu alanlara yönelmiştir.

Mekânın rasyonel olarak tasarlanması ve görece refah seviyesinin daha yüksek olduğu alanlara kent seçkinlerinin yönelmesi salgın süreçlerinde de mekânsal farklılaşmayı beraberinde getirmiştir. Kent mekanının sınıfsal olarak organizasyonu, yukarıda bahsedildiği gibi üretim ilişkileri, toplumsal hareketlerle ve salgınlarla yakından ilişkilidir.

Hastalıkların etkisine ek olarak, neoliberal süreçte yaşanan küresel ekonominin yeni rotası ve kamu hizmetlerinin özelleştirilmesi gibi yapısal değişimler, kent mekanının sınıf eksenli yapılandırılmasını yaygınlaştırmıştır. Rasyonel peyzaj üretimi, avantajlı bölgelerin üretilmesinin ve bu alanlarda egemen olma fırsatlarının (Harvey, 2016, s.52) önünü açmıştır. Bu şekilde gelişen kent yönetimi, Harvey'e göre "kapitalist karakterli kent işletmeciliğine (managerialism)" dönüşmektedir (Harvey, 2016). Rasyonel bir biçimde inşa edilen bu yapılı çevrede, güvenlik mekanizmalarının bulunması, -güvenlik görevlisi, duvarlar, dikenli teller, güvenlik kameraları- sosyal donatı alanlarının bu güvenlik mekanizmaları ile kontrol edilmesi, geniş bulvar ve sokakların bulunması, bölgenin rastlantı ve olanakların düşünülerek yapılandırıldığını göstermektedir. En ufak olasılığın düşünülerek gerçekleştirilen kentleşme formu, 
salgın hastalıklar sürecinde de karşılaşma olasılığını düşürüleceğinden enfekte olma ihtimalini de minimuma indirecektir. Dolayısıyla heterojen kalabalıkların zemini olan -mutenalaştırılmamış ve yoksul kesimlerin yaşandığ alanlarda- kentlerde, Covid-19 pandemisinin yayılma oranlarına bağlı olarak yüksek vakalarda seyrettiği görülmüştür. Çam, Covid-19 özelinde bu durumu şu şekilde aktarmaktadır;

“BM Genel Sekreteri Guterres'in kalabalık ve sıkışık olan yerleşim alanlarında Covid-19'un bulaşma riskinin daha yüksek olduğu ve dünya genelinde ortaya çıan vakaların \%90'ının kentlerde ortaya çıktığı yönündeki açıklaması kentlerdeki yoğun nüfusun virüs açısından ne derece önemli olduğunu ortaya koymaktadır" (Çam, 2020).

Yayılma ve vaka oranını en aza indirmek için telkin edilen önlemler; ev karantinası, sosyal mesafe, enfekte kişilerden temastan kaçınılması, toplu taşıma araç kullanımının en aza indirilmesi, kalabalık alanlardan uzak durulması ve sağlıklı beslenme şeklinde sıralanmaktadır. Dolayısıyla mekânın sınıfsal olarak örgütlenmesine ek olarak pandemi sürecindeki korunma biçimlerinin de sınıfsal karakter taşıması, pandeminin sınıf bağışıklığı (Elbek, 2020) olduğunu göstermektedir. Neoliberalizm bağlamında bakıldığında ise kentler, kapitalist üretime dair tartışmalarına eş olarak salgın hastalıklar bağlamında sosyal mesafe, sağlık hizmetleri ve kamusallık üzerinden tartışmaları da görmekteyiz. Günümüzde küresel anlamda söylemlerin merkezinde olan sosyal mesafe ve öz-korunma tedbirleri sinıfsal olarak da kentsel yaşam biçimlerini dönüştürücü bir nüveye sahiptir.

\section{Diyarbakır Deneyimi}

Kentsel açıdan düşündüğümüzde, özellikle kapalı yerleşim alanları bu söylemlerin mekânsal mümkünlüğünü arttırmaktadır. Bu durumun düşünsel arka planını modernist Le Corbusier'in 1918 salgınından etkilenerek sergilediği tutumdan da anlayabiliriz. Kolera salgını döneminde Le Corbusier ve Olmstead tarafindan kent planlama hastalığın yayılmasında bir önlem olarak görüldüğü bilinmektedir (Nevius, 2020). Bu durum, kentlerin sınıfsal olarak da planlama dahilinde ayrışmasına imkân vermektedir. Le Corbusier, City of Tomorrow adlı çalışmasında hijyeni vurgulayarak şehir planlama ve ev inşa etmenin salgın tecrübelerine dayanarak biçimlendirilmesi gerektiğinden bahsetmiştir. Le Corbusier'in Işlldayan Şehir olarak bilinen Radiant City projesi, şehir 
planlamanın öneminden beslenen bir diğer çalışmasıdır. Bu bağlamda, Kayapınar ilçesine ${ }^{8}$ ait fotoğraflarla karşılaştırıldığında Radiant City ile benzerliği şaşırticidir.
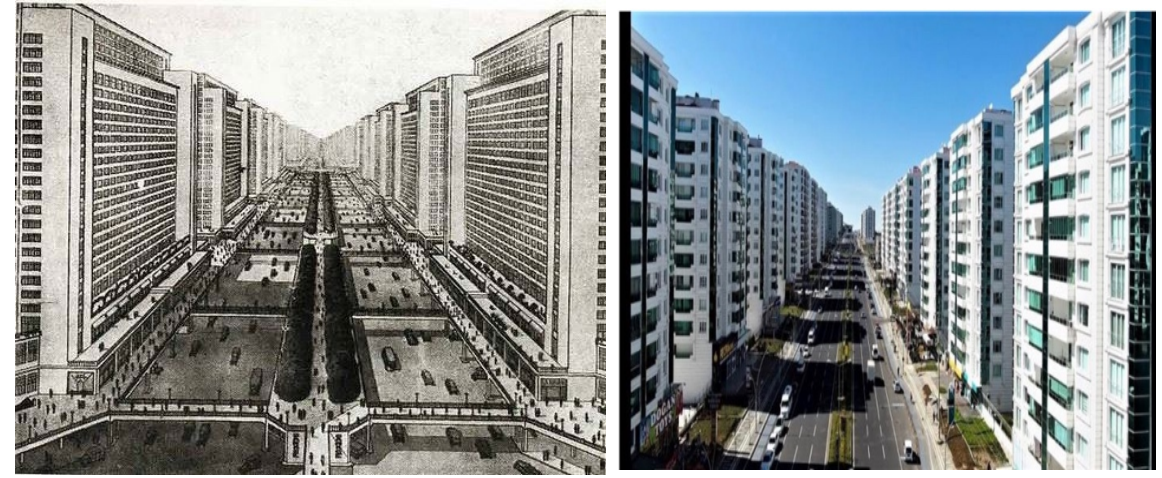

Şekil 1: Radiant City (Özmen, 2018). Şekil 2: Kayapınar iļ̧esinin görünümü. (Kayapınar Belediyesi, 2020)
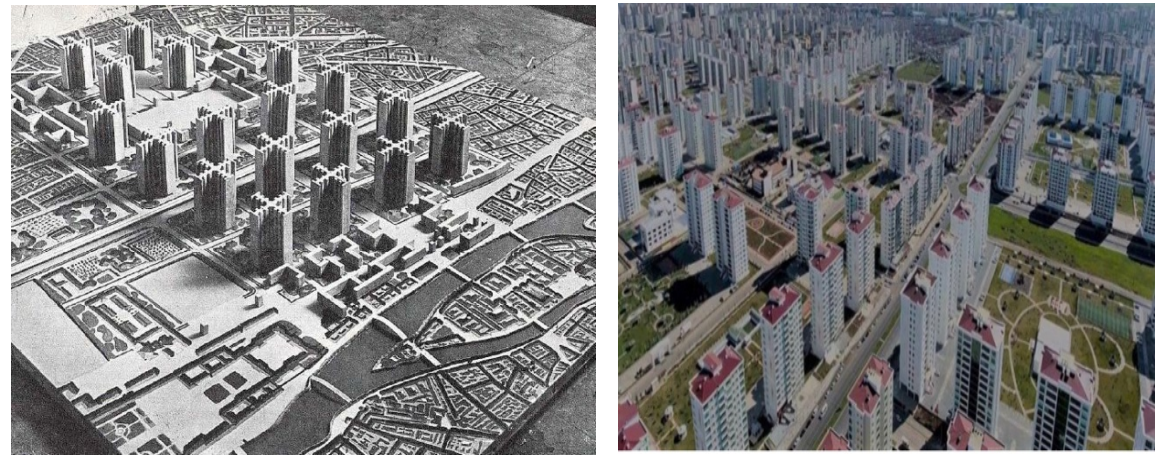

Şekil3:Radiant Gity. (Özmen, 2018). Şekil 4: Kayapınar ilçesinin görünümü. (Kayapınar Belediyesi, 2020)

1970 ve 1980'lerle beraber küresel olarak yaygınlaşan ve neoliberalizmin konut formu olarak tarif edilen Gated Communities/Kapılı ya da kapalı siteler bir bakıma Haussmann'ın mirası olduğu söylenebilmektedir. Kapalı kondiminyum ve güvenlikli siteler olarak tanımlanan güvenlikli dikey konut formu, Diyarbakır'da Kayapınar ilçesinde -özellikle, ele aldığımız Mezopotamya ve Mahabad Bulvarları

\footnotetext{
${ }^{8} 1993$ - 2004 yılları arasında, 26 bin hektar yüz ölçümünden oluşan belediye sınırı, 23 Temmuz 2004 tarih ve 25531 sayılı Resmî Gazetede yayınlanan 5216 sayılı Büyükşehir Belediyesi Kanunu ile genişlemiştir. Buna göre Vilayet Binası merkez olmak üzere büyükşehir belediye sınırı $20 \mathrm{~km}$ yarıçapında bir alanı kapsayacak biçimde belirlenmiş ve var olan belde belediyeleri de ilk kademe belediyesi statüsüne geçmiştir (Bağıvar, Çarıklı, Kayapınar). Yine aynı yasal düzenlemeyle Büyuikşehir Belediye sınırı içinde köy statüsünde bulunan 1997 kırsal yerleşim birimi de mahalle statüsü kazanmıştır (2017-2024 Büyükşehir Belediyesi Stratejik Planı).
} 
arasındaki kesimde- yaygın olarak görülmektedir. Bunun yanı sıra Diyarbakır'da ikili bir yapı söz konusudur. 'Oluşturulmuş', 'izgara', 'düzenli', 'planli', 'kurallı' olarak da anılan geometrik düzen, genellikle öngörülen ve bu öngörüye bağlı olarak gelişen bir yerleşim deseni iken, 'kendiliğinden oluşmuş', 'tesadüfî oluşmuş', 'geometrik olmayan', 'düzensiz', 'planszz', 'kuralszz' gibi ifadelerle de tanımlanan organik düzen, belli yönlendirmeler dâhilinde doğaçlama olarak gelişen bir diğer yerleşim desenidir. (Kulözü, 2016). Bu bağlamda Kayapınar'da geometrik düzeni ve temel yapı biçimi olan güvenlikli siteleri görmekteyiz. Ekonomik küreselleşmenin emlak piyasasını etkilemesi ve lüks ticari ve konut inşaatında yabanc ve yerli yatrımda büyük bir artşın yaşanması (Sassen,1991) güvenlikli sitelerin görünürlügünü arttıran temel faktördür. Güvenlikli siteler, Diyarbakır'da da 2000'ler sonrası AKP neoliberalizmi sürecinde görülen temel konut formu olmuştur. Keyder'in (2013) toplumsal kutuplaşmanın mekandaki ifadesi olarak tanımladığı bu form, yerel tarihselliği içinde analiz etmek, neoliberalizmin küresel ve yereli ilişkilendirme metodu hakkında da bilgi verici olacaktır.

2000'li yıllarda AKP dönemi neoliberalizminin mütemmim cüzü haline gelen inşaat sektörü, yeni kentleşen alanlarda kendini güvenlikli siteler formunda göstermiş̧ir. Bu dönemden itibaren yaygınlaşmaya başlayan güvenlikli konut formu, son yirmi yıllık süreçte giderek yaygınlaşmıştır. Çalışma alanını kapsayan alanda inşa edilen konutların hepsinin bu formda olması, aslında AKP neoliberalizminin mekânsal formu olan bu yapıların ulusal ölçekte yayginlaşma oranı hakkında da bilgi vericidir. 2000'li yıllar sonrasında kent ölçeğindeki üretilen konut sayısı şekil 5 'te gösterilmiştir.

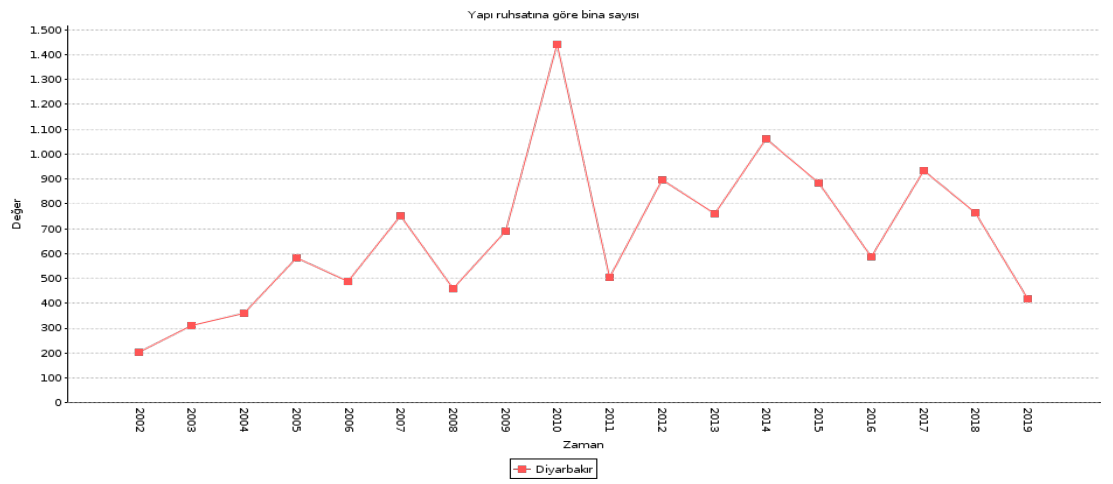

Şekil 5: Son 20 Yıldaki Yapı Ruhsat Formu İstatistikleri

Şekil 5'e bakıldığında, TÜİK verilerine göre 2010 yılında konut sayısının daha önceki yıllara kıyasla zirve yaptı̆̆ını görüyoruz. Ayrıca, 2011 yılında Diyarbakır'daki \%25'lik konut oranının Türkiye geneline kıyasla yüksekliği de dikkat 
çekmektedir. ${ }^{9}$ Diyarbakır'da 1990 ve 2011 yılları arasında konut üretiminin iki katına çkarak kent sınırları içinde 150.000 konutun inşa edilmiştir (Genç, 2014, s.244). 1999 ve 2000 yılları arasında Şanlıurfa Bulvarı ve Elâzı ğ Bulvarı arasındaki bölgede yapılaşma \%85'e kadar çkmıştır. Söz konusu alan, yürürlükteki imar planında da kentin gelişme bölgesi olarak tanımlanmaktadır (Planlama Tarihi, 2012).

Diyarbakır'ın tarihsel seyri içinde bakıldığında, Sur'dan Kayapınar'a doğru bir kentleşme akışı söz konusudur. Dolayısıyla kentleşmenin son ayağı olarak Kayapınar ilçesi, Kayapınar ilçesinde de Mahabad Bulvarı (yeni kentin merkezi noktası) ve üst kısmı tanımlanmaktadır. Mahabad Bulvarı ile Mezopotamya caddesi arasında kalan kısımda yer alan güvenlikli siteler, sadece konut formundan ziyade yeni kent mekanının örgütlenme biçiminde de oluşturmaktadır (Karadas,2020). Kentin dışa doğru sıçrayarak yaşadığı bu büyüme süreci, eski alanların orta-üst sinfflar tarafindan terk edilmesiyle çöküntü alanlar haline gelmektedir. 1960'lardan itibaren sur içindeki geleneksel evlerin, fiziki olarak bozulmaya başlaması, beraberinde çöküntü bölgelerinin oluşmasını sağlamış ve kentte nüfus yoğunluğunun sürekli artmasıyla, yeni yerleşim alanlarının oluşmasını tetiklemiştir. Bu durum, Lefebvre'nin Şehir Hakkı isimli çalışmasında da içe ve dışa doğru patlamalarla kentin büyüdüğü şeklinde yer almaktadır; dolayısıyla, yeni yerleşim alanlarına kıyasla eski kent merkezlerinin çöküntüye dönüşen bir dinamiği bulunmaktadır. Kentin Kayapınar ilçesi üzerinden gelişmesi kent ekseninin de kayarak, merkezin yeni yapılaşan yerleşim alanlarına kaymasına neden olmuştur. Ayrıca, Karacadağ Kalkınma Ajansı verilerine göre Kayapınar ilçesi 400.905 nüfusuyla en çok popülasyonu barındıran ilçedir (Karacadağ Kalkınma Ajansı, 2020, s.7). İkinci en kalabalık ilçe ise Kayapınar ilçesinden daha dar bir alanda konumlanan - bir sonraki haritada da görüleceği üzere- Bağlar ilçesidir.

\footnotetext{
${ }^{9}$ Detaylı bilgi için bknz:

Karacadağ Kalkınma Ajansı. (2018). İstatistiklerle Diyarbakır.
} 


\begin{tabular}{|c|c|c|c|c|}
\hline İlçe & Toplam & Erkek & Kadın & Oran \\
\hline Kayapınar & 400.905 & 202.923 & 197.982 & $22,48 \%$ \\
\hline Bağlar & 399.499 & 200.694 & 198.805 & $22,40 \%$ \\
\hline Yenişehir & 214.831 & 108.032 & 106.799 & $12,05 \%$ \\
\hline Ergani & 134.497 & 68.217 & 66.280 & $7,54 \%$ \\
\hline Bismil & 118.605 & 59.254 & 59.351 & $6,65 \%$ \\
\hline Sur & 102.114 & 51.343 & 50.771 & $5,73 \%$ \\
\hline Silvan & 87.639 & 44.315 & 43.324 & $4,91 \%$ \\
\hline Çınar & 76.798 & 38.615 & 38.183 & $4,31 \%$ \\
\hline Cermik & 51.058 & 25.666 & 25.392 & $2,86 \%$ \\
\hline Dicle & 37.534 & 18.989 & 18.545 & $2,10 \%$ \\
\hline Kulp & 35.449 & 17.787 & 17.662 & $1,99 \%$ \\
\hline Hani & 33.048 & 16.902 & 16.146 & $1,85 \%$ \\
\hline Lice & 25.027 & 13.121 & 11.906 & $1,40 \%$ \\
\hline Eğil & 22.381 & 11.288 & 11.093 & $1,25 \%$ \\
\hline Hazro & 16.779 & 8.540 & 8.239 & $0,94 \%$ \\
\hline Kocaköy & 15.974 & 8.134 & 7.840 & $0,90 \%$ \\
\hline Çüngüş & 11.293 & 5.696 & 5.597 & $0,63 \%$ \\
\hline
\end{tabular}

Şekil 6: İlçeye Dayalı Nüfus Bilgileri (Karacadağ Kalkınma Ajansı, 2020).

Sermaye Kentleşmesi (Harvey, 2015, s.295-327; Şengül,2009) bağlamında gelişen Kayapınar ile Diyarbakır'daki toplumsal hareketliliği ve kentsel yoksulluğu yoğun biçimde deneyimleyen Bağlar ilçesi açısından önemli bir farklılık vardır. Bağlar özellikle zorunlu göç, düşük yoğunluklu çatş̧ma ve işsizlik gibi birçok nedenden dolayı yoğun nüfus barındırmıştır. 1945 yılından itibaren Suriçi bölgesinde yerli ailelerin bölgeyi terk etme eğilimleri arttıkça, bölgedeki dar gelirli kesimin yerleşimi de aynı oranda artmıştır (Kejanlı ve Dinçer, 2010). Benzer sosyo-ekonomi durum, Bağlar için de geçerlidir.

Aşağıdaki haritada da görüldüğü üzere, ilgili rapora göre; Bağlar ilçesini oluşturan mahalleler, kentin nüfus yoğunluğu en yüksek mahalleleridir. Nüfus yoğunluğunun yüksek olduğu alanlarda kişi başına düssen yeşil alan, eğitim, sağlık, kültürel tesis alanı miktarları azalmaktadır. "Bağlar ilçesi bu yapıları ile kentsel yoksulluğun yanı sıra, kentsel hizmetlerin sunumlarının yetersizliğinden kaynaklanan mekânsal sorunlarla da karşı karşıyadır" (2012, s.56). Bağlar Belediyesi'nin 2024 Stratejik Raporu'nda paylaşlan ankette katılanlara göre, Bağlar 'da yaşamaktan duydukları memnuniyet dereceleri sorulmuş ve cevaplayanların $\% 28^{\prime} \mathrm{i}$ memnun olduğunu, \%36'sı kısmen memnun olduğunu, \%34'ü memnun olmadığını söylemiştir (Bağlar Belediyesi, 2019, s.29). 


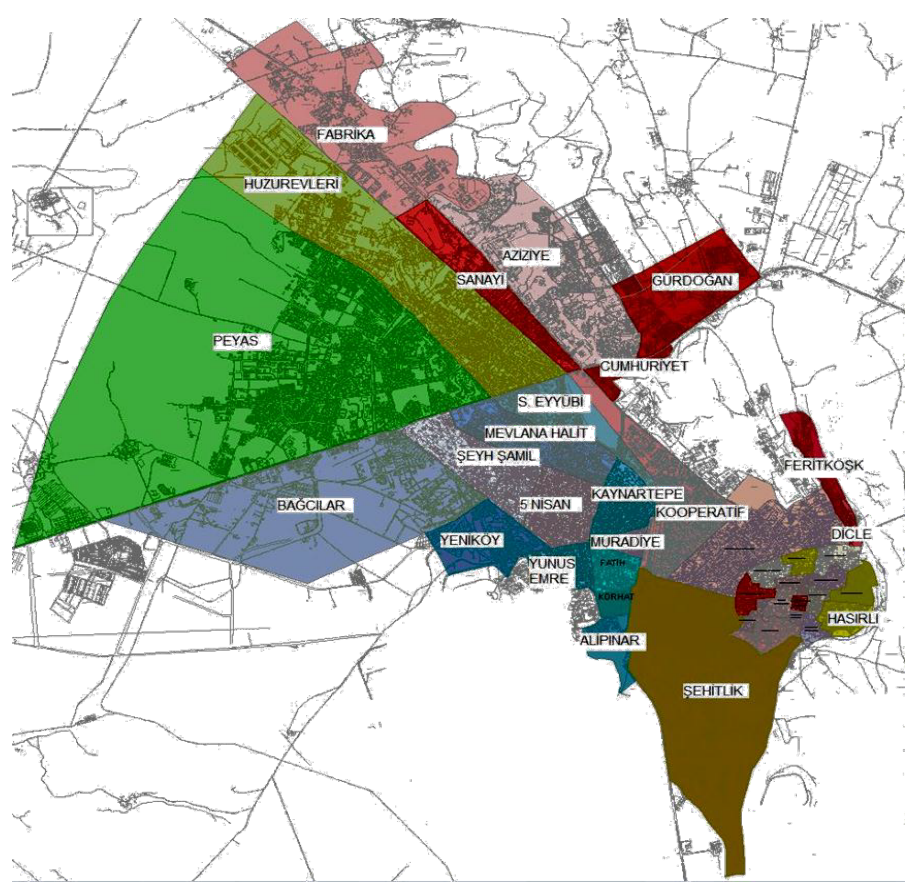

Şekil7:Şanlıurfa DiyarbakurKentsel AltBölgeKalknnma Yaklaşmı Raporu(Karacadağ Kalkınma Ajansı, 2012, s.56).

Ayrıca, ilçe içinde az miktarda yeşil alan olması da yoğunluğun özel mekânda yoğunlaşmasına neden olmaktadır. Bu duruma ek olarak, yoğun popülasyonun barınma ihtiyacını gidermek için gecekondulaşma eğiliminde olduğu da görülmektedir. Dolayısıyla, bu durum da kamusal mekanların ihlal edilerek konutlaşmasına neden olmaktadır. Kayapınar' da ise sitelerin kendine ait yeşil alan ve sosyal donatılarının olması ve gecekondulaşmanın hiç olmaması iki alanı farklılaştırmaktadır. Dolayısıyla, bu durum beraberinde mekânsal ve toplumsal ayrışmayı getirmekte ve sonucunda; kent, herkes tarafından paylaşılan bir kamusal alan olma özelliğini kaybetmektedir.

Pandemi sürecinde hastalığın mekânsal etkisini etkileyen bir diğer önemli durum nüfus yoğunluğudur. Kayapınar'da metrekareye düşen kişi sayısının düşük olması ve konut açısından bir yığılma söz konusu olmaması pandeminin bu ilçede daha düşük oranla deneyimlenmesini sağlamaktadır. Adrese Dayalı Nüfus Kayıt Sistemi (ADNKS) 2017'ye göre, Bağlar ilçesinde ortalama hane halk1 oranı 4,89 iken Kayapınar ilçesinde 4.77'dir. Yüz ölçümü açısından bağlar ilçesinin daha dar bir alanda konumlanması, bu sayının daha yoğun bir biçimde yaşanmasına neden olmaktadır (Karacadağ Kalkınma Ajansı, 2018). Buna ek olarak, Bağlar ilçesine baktığımızda enformel yapıların yoğun olduğunu ve kentsel yığılmanın yaşandığını görmekteyiz. Bağlar ilçesinde işçi sınıfının yoğun olması ve karantina 
süresince çalışmak zorunda olmaları da pandeminin ilçede yayılma oranını artırmaktadır. Bunun yanı sıra, kalabalık hane nüfusuna sahip olmaları ve hane alanının Kayapınar'daki konutlara kıyasla küçïk olması, salgının yayılma hızının artmasına neden olmaktadır. Özellikle özel alan olan ev mekânında kalma süresinin \%35 artth̆ (Universus Sosyal Araştırmalar Merkezi, 2021) bu süreçte, güvenlikli konutlar sınıf merkezli ve eşitsiz bir korunma biçimi olarak karşımıza çıkmaktadır. Sağlık Bakanlığı tarafından "Covid-19 Evde İzlem Önerileri” kapsamında, yapmış olduğu öneriler de konut formu ve hane halkı yoğunluğuyla doğrudan ilişkilidir. Bu rapora göre, "kişiler; ayrı odalarda kalmall, ayrı tuvalet ve banyo kullanmalı, ortak mutfak gereçlerini mümkün olduğu kadar ayırmalı ve temastan olabildiğince kaçınmalıdır." TÜİK tarafından 2008-2020 yılları arasındaki hane halkı büyüklüğü raporunda da görüldüğü üzere, Diyarbakır 2008'de 6,30 olan yoğunluk oranını 2020 yılında 4,54 oranına düşürmüştür (TÜİK, 2020). Fakat 2020 yılında Türkiye ortalaması olan 3,38 oranını üzerinde kaldığı görülmektedir. Dolayısıyla, pandemi sürecinde Covid-19 bulaş riskinin, Diyarbakur'da daha yüksek olması olasıdır. Bu verilerle kıyaslayarak, kent mekanının sermaye merkezli kentleşmesi ve pandemi sürecinde de görüldügü gibi salgın hastallğın görülme biçimini ve oranunı etkileyen temel faktörlerden biridir.

Kent merkezi için oldukça büyük öneme sahip olan kamusal mekanlar, kentleşme sürecindeözel alan-kamusal alan çekişmesi nedeniyle, sınırların oldukça değişken olabileceğini göstermektedir. Güvenlikli site duvarlarının inşa edilirken sokak, cadde ve kaldırım gibi alanları içine almasıyla bu kamusal mekanları zayıflatmaktadır. Salgin sürecinde de zayıflayan bu kamusal mekanlar özellikle kentin mülksüzleri için olumsuz etkiye neden olmaktadır. Böylece, ev içi mekânı dışında sosyalleşemeyen kesim, salgının olumsuz sosyo-ekonomik arka planına ek olarak psikolojik olarak da zarar görmektedir.

Barton ve Grant (2006) tarafından, Margaret Whitehead ve Göran Dahlgren'in (1991) "gökkuşağı modeli"nin üzerine ekosistem ve küresel iklim koşullarının da eklenerek detaylı bir modeli olarak oluşturulan çalışması "Sağ lık Haritası" nda görüldüğü gibi, sağlıklı olma ve bireyler için sağlık küresel ekosistem, doğal çevre, yapılı çevre, faaliyetler, yerel ekonomi, topluluk, yaşam tarzı ve halk olarak birbirini tamamlayıcı dinamiklerle sağlanır. Bu modelde halk sağlığı ekonomik, çevresel ve toplumsal eşitsizliklerden bağımsız düşünülemez. Birbiri ile iç içe geçmiş doğrudan veya dolaylı olarak halk sağlığını etkilemektedir. Dolayısıyla, bu zincirin tam ortasında yapılı çevrenin yarattığı kopuş, bütün toplum için tamamen sağlıklı olma halini ortadan kaldırarak bu yaşam alanını sekteye uğratır. Ayrıca, TTB tarafından yayınlanan raporda da belirtildiği gibi, "kentlerde sağlık hizmetleri tartışmalarını 
yürütürken yapılacak önemli bir saptama, kapitalist toplumsal yapı ve üretim ilişkileri içerisinde sağlığın ve sağlık hizmetlerinin kapitalizmin gereksinimleri doğrultusunda şekillendirildiği" söz konusudur (TTB, 2007, s.12). Bu sonuca benzer olarak, Gehl ve ekibi tarafından yaklaşık 2000 kişiyle yapılan çalışma da "pandemi sürecinde herkese açık kamusal alanların kullanılmadığını, yani hayalet mekân olduğu" sonucu ortaya çıkmıştır. ${ }^{10}$ Salgın döneminde söylemlerin merkezinde olan kamusal mekanlar, sermayenin kentin örgütlenmesinde önemli bir rol oynaması nedeniyle, dönüşen en önemli alanlardır. Bu dönüşüm sonucu hayalet mekanlara dönüşen alanlar toplumsal ilişkilerin zayıflamasına ve kamusallığın deforme olmasına neden olmaktadır. "Kentteki âtıl kalmış veya terkedilmiş kamusal alanları tanımlamak için kullanılan hayalet mekanlar; tasarım, güvenlik, erişilebilirlik, çevresel kalite ve mekân kullanımı gibi özelliklerden yoksunluğundan dolayı ortaya çımaktadır" (UNDP, 2020). Yapılı çevrenin durumu salgın sürecinde belli bir kesim için koruma sağlamaktadır. Özellikle, yabancıların kısıtlandığı sosyal donatı alanları bu süreçte site üyeleri için mülkiyet koşullu bir özgürlük alanı sağlamıştır.

Kayapınar ilçesindeki, sağlık hizmetleri yapıları ele alındı̆̆ında, Kayapınar ilçesinde altı özel hastanenin yer aldığını görmekteyiz. Kayapınar ilçesinde sağlık hizmetlerine ulaşmanın kolaylığı ve satın alınabilir olması salgın sürecinde enfekte olan bireylerin maddi koşulları sayesinde uzak mesafe gitmeden ilçe içinde tedavi görebileceği bilgisini vermektedir. Buna karşın Bağlar ilçesine baktığımızda hem devlet hastanesinin olmadığını hem de bölgedeki iki özel hastanenin üçüncü düzey yoğun bakım servislerinden mahrum olduğu için pandemi hastanesi ilan edilmediğini görülmektedir. Bu durumlara ek olarak, genelde küreselleşme, yerelde ise AKP neoliberalizmi ile sağlığ1 kamusal bir hak olmaktan çıkartan ve devletin sorumluluğunu yurttaşa aktaran ve sağlık alanını tamamen meta karakterine dönüştüren bir piyasanın (TTB, 2007, s.8) geliştirilmesi, emarelerini sağlık ocaklarının lağvedilerek Aile Sağlı̆̆ı Merkezleri'nin açılmasına zemin hazırladığı sürece değinmek gerekir. TTB tarafından Kentlerde Sağlık Hizmetlerinin Örgütlenmesi: Çok Yönlü Yaklaşım adlı raporda, bu durum şu şekilde analiz edilmektedir; "Şehir planlamasinda sağglk kurumlarnna uygun yer ayrlmaması, kent planlarını rant üzerinden yapılması, sosyal politikalarm terk edilmesi kentlerde sağlık hizmetlerinin

\footnotetext{
${ }^{10}$ Detaylı bilgi için bknz:

Gehl People. (2020). Public Space Plays Vital Role in Pandemic
} 
nüfus tabanlı örgütlenmesinin önünde temel bir engel oluşturmuş, bu da sağllk ocaklarnna erişilebilirliği engellemiştir" (TTB, 2007, s.37). Dolayısıyla böyle bir süreç, sağlığa erişimde eşitsiz ilişkilerin kök salmasına ve sınıfsal boyutunun daha derinleşmesine neden olmuştur. Bu bilgiler ışığında, Bağlar ilçesinde enfekte biri ya ilçe dışında yer alan devlet hastanelerine ya da kentin çeperinde -Kayapınar'da- bulunan eğitim araştırma hastanesine gitmek durumunda kalmaktadır. 3 Eylül 2020 tarihinde TUIKK tarafından yayımlanan Ağustos 2020 Tüketici Fiyat Endeksi'nde ana harcama gruplarında hane halkları harcama gruplarında yıllık değişim oranlarında en önemli artış \%14,68 ile sağlıkta olmuştur. Hane halkı sağlık harcamaları tıbbi ürünler, aletler ve malzemeler, ilaç, ayakta ve yataklı tedavi hizmetleri gibi kalemlerden oluşmaktadır (TTB, 2007, s.80). Devlet hastanelerinde yatak dolum kapasitesine ulaşıldığını -ki 2007-2013 yıllarını kapsayan Dokuzuncu Kalkınma Planı'nda, sağlık personeli sayısı, yatak sayısı ve kullanım oranları, bebek ölüm hızı, aşılama gibi göstergelerde yaşanan iyileşmelerde henüz istenen düzeye ulaşılamadığı, sağlık hizmetleri sunumunun bölgesel ve kent-kır düzeyindeki dengesizliğinin sürdüğü ve hastanelerin mali ve idari özerkliğe kavuşturulması ihtiyac1nın devam ettiği gibi gündem maddelerine yer verilmiş olması (On Birinci Kalkınma Planı (2019-2023), 2018, s.9) ve devlet söylemleri göz önünde bulundurulduğunda, toplu taşıma kullanmanın ve uzun mesafe gitmenin pandemi sürecinde hayati tehlike doğurduğu bilinmektedir. Sağlık Bakanlığı'nın verilerine göre ölüm oranlarının en çok olduğu kentlerden biri Diyarbakır'dır (T.C. Sağlık Bakanlığı, 2020). Vakaların ve ölümlerin bu denli yüksek olduğu Diyarbakır özelinde, Kayapınar'daki durum ile Bağlar'daki durum karşılaştırıldığında pandeminin maddi koşullar altında deneyimlendiği gözlemlenebilmektedir. Bu süre zarfından resmi makamlarca şeffaf veriler sağlanmamış olsa da Şekil 8, Şekil 9, Şekil 10 ve Şekil 11'deki haritalardaki renk tonlarından Bağlar ve Kayapınar ilçesinde pandemi sürecinin yoğunluğu hakkında bilgi vericidir. Bu haritalar Ocak 2020 ve Ağustos 2020 tarihlerinde alındığı için sürece dair fikir vermektedir. 


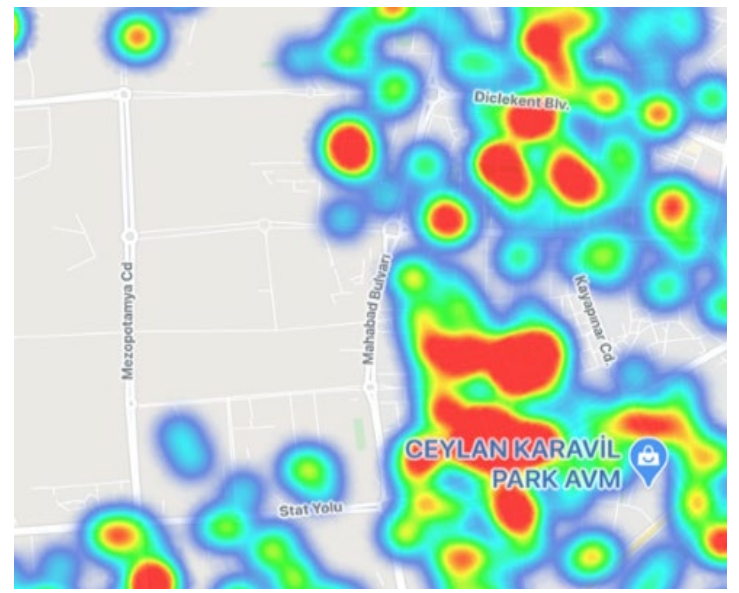

Şekil 8: Kayapınar İlçesi Vaka Haritası- 15 Ocak 2020 (Hayat Eve Sığar, 2020)

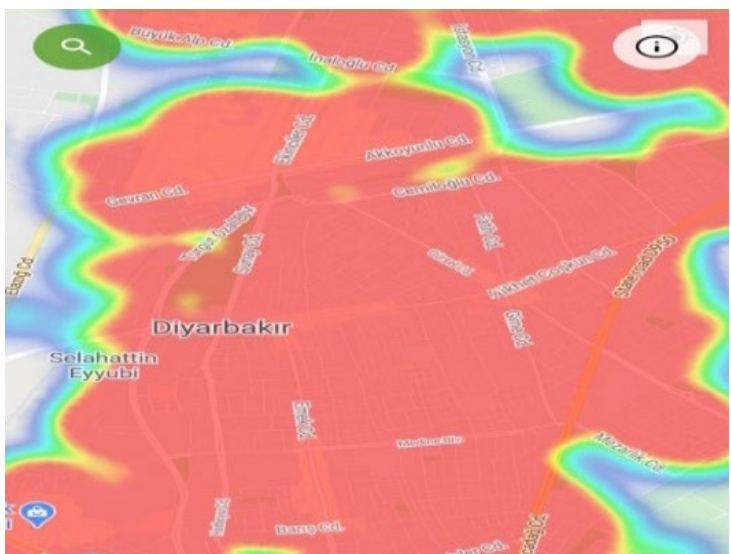

Şekil 9: Bağlar İlçesi Vaka Haritası- 15 Ocak 2020 (Hayat Eve Sığar, 2020) 


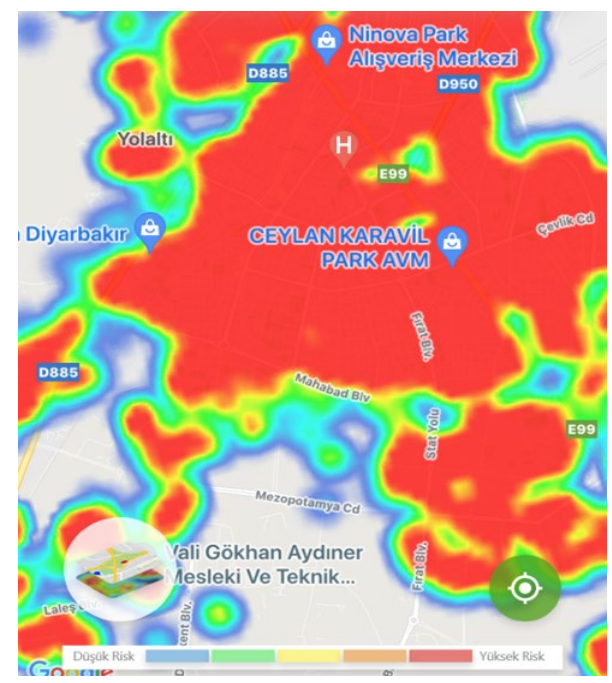

Şekil 10: Kayapınar İlçesi Vaka Haritası - 15 Ağustos 2020 (Hayat Eve Sığar, 2020).

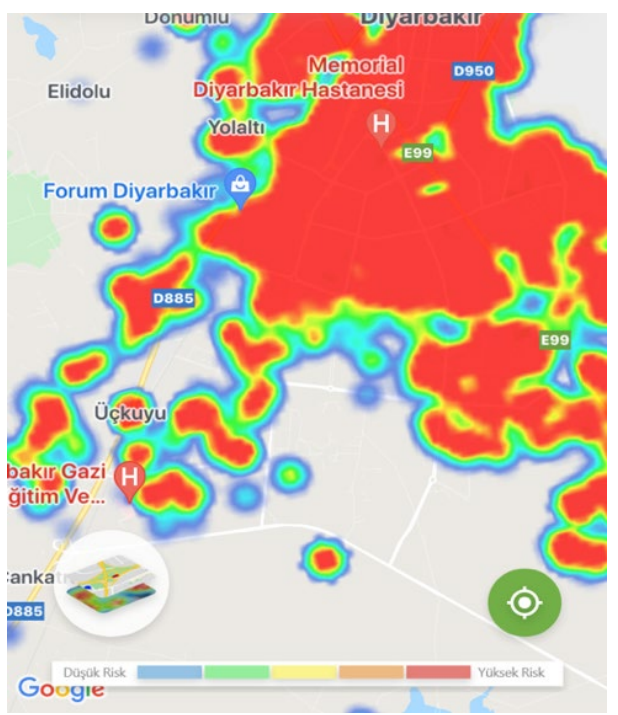

Şekil 11: Şekil 10: Bağlar İlçesi Vaka Haritası 15 Ağustos 2020. (Hayat Eve Sığar, 2020).

Yukarıdaki ilk haritada görüldüğü üzere Bağlar ilçesi ve Kayapınar ilçesini kıyasladığımızda kent çeperlerinde bölgenin yeşil rengini yoğun olduğu ve vaka oranının azaldığını görmekteyiz. Çalışma alanımız olan Mahabad Bulvarı ve Mezopotamya caddesi arasında kalan bölgede vakanın en düşük seviyede görülmesi dikkat çekicidir. İkinci haritada ise alanın tamamen kırmızı olması Kayapınar ilçe- 
sine kiyasla pandeminin Bağlar ilçesinde çok yüksek oranlarda görüldüğünü göstermektedir. Şekil 10 ve Şekil 11'e baktı̆̆ımızda ise benzer durumun 6 aylık süreç sonrasında da devam ettiği görülmektedir. ${ }^{11}$

Bu tablonun daha anlaşılabilir kılınması adına bu noktada birkaç ekleme yapmak gerekmektedir. Diyarbakır Bağlar Belediyesi 2020-2024 Stratejik Plan'ına göre, Bağlar ilçesi 1993 yılında Diyarbakır, büyükşehir belediyesi statüsünü aldığında Bağlar Belediyesine 'de yedi mahalle daha eklenmiştir. Sonraki süreçte 2004'te- Bağlar ilçesine yeni alanların eklenmesi ile ilçe, Diyarbakur'ın en büyük ilçesi haline gelmiştir. (Diyarbakır Bağlar Belediyesi 2020-2024 Stratejik Planı, 2019). Söz konusu Covid-19 risk haritasında Bağlar ilçesinin merkez Bağclar ve diğer altı mahallesi yer almaktadır. Daha sonra dahil edilen mahaller yine güvenlikli sitelerin inşa edildiği yerler olmaktadır. Bu anlamda diyebiliriz ki; Bağlar ilçesi 2006 sonrasında kendi içinde de sosyo-mekânsal olarak bölünmüştür. Ayrıca, Bağlar ilçesi 1980'ler sonrası yaşanan zorunlu göçün ilk durağı olmaktadır. Göçilenüfusu artan ilçede, konut tipi kayıt dışı olduğundan imar kriterlerine uygun bir şekilde inşa edilmemiştir. Buna ek olarak, zorunlu göç sonrası nüfusun \%58'inin tek katlı müstakil evlerde yaşadığı tespit edilmiştir (Yıldırım, 2020, s.112). Bunun yanı sıra, bölgede 2014 yılında yapılan Karacadağ Kalkınma Ajansı'nın Yaşam Kalitesi Endeksi Araştırması'na göre, "Eğitim endeksinde Bağlar ve Kayapınar arasındaki eğitim endeksi arasından beş kat kadar bir fark vardır. Sağlık endeksinde ise (Hastane yatak, eczane hekim sayıları aile sağlık merkezlerindeki muayene yoğunluğu kaba ölüm hızı ile bebek ölüm hızı verileri esas alınarak oluşturulmuş̧ur) yaklaşık olarak üç kat kadar bir fark söz konusu olmaktadır" (Karacadağ Kalkınma Ajansı, 2014). Yaşanan bu büyük farklılık, gündelik yaşamın ve pandemi sürecinin sınıf ekseninde deneyimlenmesine etkide bulunmuştur. Yapılı çevrenin salgin esnasında sağladığı bu kalkan, Bağlar'da görülmediği ve aksine gecekondulaşma eğilimi ile yoğun popülasyona sahip olduğu için vaka oranlarını çok yüksek oranlarda görülmektedir. Sınıfsal olarak değerlendirildiğinde çalısma zorunluluğu bulunmayan-ki karantina döneminde alınan kararlarla 20 yaş altı çalışan kesimin bu karantina yasağından muaf tutulması sürecin sermaye merkezli geliştiğini de vurgulamaktadır- bireyler için hayatın eve sığması daha muhtemel iken, çalışma zorunluluğu -özellikle Bağlar ilçesinde enformel sektörde çalışan kesim

\footnotetext{
${ }^{11}$ Bu sürece ilişkin veri elde etmek amaçlı, Sağlık Bakanlığı, İl Sağlık Bakanlığı, İlçe Sağlık Bakanlığı ve TTB Diyarbakır ile görüşmeler gerçekleştirilmiş, fakat sürece ilişkin veri paylaşımının mümkün olmadığı ifade edilmiştir. Özellikle, pandeminin ilk dönemlerinden itibaren pandeminin sınıfsal olarak deneyimlenmesi odağındaki tartışmaların gündemi sürekli meşgul etmesi, bu noktada temel argümanımızı destekler niteliktedir.
} 
için- olan bireyler için pandemi süreci daha zorlayıcıdır. Dolayısıyla, bu çerçeveden, Kayapınar'daki kapılı-kapalı yerleşim alanlarda yaşayan kesimin hayatının eve sığabildiğini, Bağlar ilçesinde barınan kesim için ise hayatın evden taşmak zorunda olduğunu çkarabiliriz.

\section{Sonuç Yerine}

Mekânın sermaye için artı değer yaratması veya el koyma aracı haline gelmesi, mekânı üretim amacını kullanım değerinden değişim değerine doğru dönüştürmüştür. Böylelikle, kent politikaları ve kentsel mekân bu zeminde şekillenmiştir. Sermaye getiren bir meta haline gelerek sektörleşen kent mekânı ve konut alanları; yeni bir form kazandırırken, kamu hizmetleri ve kamu yararı gözetilmeksizin ekonomik canlanmanın işlevsel aracı haline gelmiştir. Şehir planlanmasının arkasındaki kapitalist kâr mantı̆̆ı, toplumsal eşitsizliği körüklerken, sosyo-mekânsal ayrışmanın somut hallerini inşa etmektedir. Dolayısıyla, Türkiye ve Diyarbakır özelinde de gerçekleşen bu durum, pandemi sürecinde de ne türden tehlikelerin olduğunu bize göstermiştir. Neoliberal kapitalizmin beraberinde getirmiş olduğu sermaye kentleşmesi projesi, dünyanın çoğu yerinde benzer deneyimleri de beraberinde getirmektedir. New York'ta da Covid-19 süresince kent yoksullarının diğer kesimlere oranla iki kat daha fazla öldüğü ve işçi sınıfı ve yoksul kesimlerin bu süreçten daha büyük yaralar aldığı açıkça bilinmektedir (Durkin, 2020). Bu duruma benzerdir diğer örnek Los Angeles deneyimidir. Los Angeles'ta mekânın s1nıfsal ve etnik dinamiklerle bölünmüşlüğü, Covid-19'a yakalanan kesimlerin sayllarına da yansımıştır. Böylelikle, Los Angeles ve New York'ta etnik azınlıkların arasında görülen vaka sayılarının çok daha fazla olduğu görülmüştür. (UCLA,2020; Durkin,2020). Tibbi antropolog olan Merrill Singer ve Snipes (1992), SAVA adını verdikleri sindemik ${ }^{12}$ etkileşim sonucunda oluşan ağır etkilerin, çok düşük gelirli gruplar ve etnik azınlıklar arasında görüldüğünü tespit edilmiştir. Söz konusu durumun, Covid-19 özelinde çoğu yerleşim alanında geçerli olduğu şüphesizdir ve özellikle yoksul ve kırlgan grupların sindemik durumlardan daha fazla etkilendiği açıktır. BM Genel Sekreteri Antonio Guterres de Covid-19 pandemisi kapsamında, özellikle düşük ücretle çalışan, savunmasız ve küçük-orta ölçekli işletmelere odaklanılması gerektiğini vurgulamıştır. Buna ek olarak, İnsan Hakları

\footnotetext{
12 Sindemi, Sinerjistik Epidemi tamlamasının tek kelimeye kısaltılmış hali olan bu kavram, genel olarak birden fazla tıbbi kondisyonun birbirini besleyerek verili siyasal ve toplumsal koşulların da içerisinde kendi çaplarının çok ötesinde ve genellikle daha kötü sonuçlara yol açmasını tanımlama hedefiyle ilk defa 1992 yılında Merill Singer tarafından önerilmiştir (TTB, Covid-19 Pandemisi 9. Ay değerlendirmesi, s. 3)
} 
Bildirgesi'nde, sağlığa ulaşabilme hakkının "hiçbir smıfsal ya da etnik koşul altında kişinin elinden alınamaz" olduğu da açkç̧a vurgulanmaktadır. Fakat, kapitalizm sağlık hizmetlerini bir metaya dönüş̧ürerek sağlık hakkı mefhumuna tamamen zit bir ilişki biçimi getirmiştir. Sağlık hakkının temel koşulu, sağlık hizmetlerinden yararlanma hakkının eşit, ulaşılabilir, tüm nüfusu kapsayan, ücretsiz ve nitelikli olmastdır. Bununla beraber TTB, kentlerde sağlık örgütlenmesinin ilkeleri bağlamında, sağlık hizmetlerinin halka en yakın konumda ve ulaşlabilir olması önemle vurgulanmaktadır (TTB, 2007). Bu vurgu, Kayapınar ve Bağlar ilçesi karşlaştırmasında da görüldüğü gibi, sağlık hizmetlerinin ulaşılabilir olması bulaşıı bir hastalık olan Covid-19 pandemisi için oldukça önemli bir durum olmuştur. Bağlar ilçesinde yeterli sağlık hizmetlerinin -devlet hastanesi- olmaması gibi Kayapınar'da hem devlet hem de özel hastane sayılarının fazla olması sağlığa fiziksel olarak ulaşmanın da önemini ortaya koymaktadır. Bununla bağlantilı olarak bir diğer önemli olgu toplu ve özel araçların kullanımı ile ilgilidir. COVID-19 pandemisiyle birlikte bir kısım beyaz yakalının evden çalışma sistemine geçmesi, araç sahiplerinin ise özel ulaşımı tercih etmesiyle kamusal toplu ulaşımdaki yük önemli ölçüde azalmıştır. Ancak bu durum sosyoekonomik bir özellik göstermektedir ve orta-alt sınıfa mensup olanların toplu taşıma araçlarını kullandıkları gerçeğini değiştirmemiştir. (TTB, 2020, s.71).

Kapitalizmin sermaye çevresi yaratması, artı değerin absorbe edilmesi ve mülksüzleştirme yoluyla birikimin temel metodoloji olması hem kent içinde hem de toplum içinde ayrışmaya neden olmuştur (Harvey, 2003). Dolayısıyla, sermayenin kentleştiği alanlar dışında kalan daha eski yerleşim alanları, salgın sürecinde de daha büyük kayıplar yaşamış olma durumundadır. Böylesi derin bir sorunun giderilmesi için mevcut kentsel formun ötesinde eşitlikçi ve demokratik bir kent mekânının inşası gerekmektedir. Kentsel düzene yönelik bu karşı çkış, kapitalizme karşı çkışı gerektirir. "Sermayenin sermayesi olan kentler" (Harvey, 2015) kapitalizmin atardamarını oluşturmaktadır. Bu anlamda kent hakkı sadecekentsel politikalar sınırlamak değildir, kapitalizmin kapsamlı bir eleştirisi niteliğindedir. Pandemiyle birlikte tekrar gündeme gelen değişen konut yapılanı, yeşil alanların önemi, ulaşımın planlanması ve kamusal alanların herkes için yeniden planlanması aslında eşitsiz toplumsal ilişkilerin ve kent formunun yeniden düzenlenmesi için bir firsat olarak görülmelidir. Çünkü pandemi aracllğıyla sermaye merkezli durmaksızın gelişen kentlerde belli bir zümrenin tek başına kurtulamayacağını ve bunun ancak bütünsel bir biçimde inşa edilebileceğini gördük. Çin'deki virüsün, Diyarbakır' da bizleri ev karantinasına mecbur bırakması daha başka nasıl okunabilir? Dolayısıyla yaşadığımız bu yıkıc pandeminin bilgisiyle geleceğin kentleri 
üzerine düşünmek, bugünün sorumluluğudur. Kamusal alanın hayalet mekanlara dönüşmesi, sınıf merkezli topluluklar ve kent mekânın inşa edilmesi, kapitalizmin dur durak bilmeyen art değer arzusu; kentsel yaşamı parçalayan bu sürece ivme kazandırmaktadır. Sorulması gereken asıl soru şudur; bu dönem, kentlerimiz ve kentsel mekanlarımızın geleceği için bir fırsata dönüştürülebilir mi? Bu çalışmanın da temel motivasyonu, aciliyetle sormamız gereken bu soruya yerel ölçekten katkı sunma derdidir. 


\section{Extended Abstract}

\section{Socio-Spatial Inequalities and City Planning in the Shadow of the Covid-19 Pandemic: The Case of Diyarbakir}

\author{
Esra Karadaş ${ }^{13}$ \\ ORCID: 0000-0003-0415-4464
}

\author{
İsmail Ekinci 14 \\ ORCID: 0000-0002-1434-6593
}

During the Covid-19 pandemic, the most iconic examples and situations surely interested in isolated public spaces and social relations that had almost reached the point of rupture. The cities, which Kaygalak defined as a "center of trouble" in the context of epidemics, witnessed a similar situation during the Covid-19 pandemic process. Epidemics that have affected modern urban planning and social integrity have deepened the sharp separation in cities in this process, and this situation has become distinctly apparent. As we know, the issues that occupied the agenda were the discussions based on this inequality in the most critical moments of the pandemic process.

In the pandemic process, as experienced in the neoliberal era, the continuation of capital-centered policies caused not to take precautions against the epidemic risk by the countries at the first stage, resulting in high death rates in metropolises. In this process, the measures taken by the governments against Covid-19 were primarily aimed at not deepening the economic crisis. Thus, the impact of COVID-19 can be described as "The effect of the COVID is to couple income inequality with health inequality, already existing but now greatly" (Graduate Institute Geneva, 2020). Also, the measures of the Turkish Government showed that this discourse is correct and applicable. For instance, the discourses such as "Stay at Home," "Social Distancing," and "Life Fits Home" are reconciling preventive measures with individual obligations comes to the fore. In this sense, the power(s) calling the working class to production has developed a neoliberal discourse by saying "Stay at Home"

\footnotetext{
${ }^{13}$ Phd Student, Ankara University, E-mail: karadassesr@gmail.com

${ }^{14}$ Graduate Student, İstanbul University, E-mail: ziryap@gmail.com

idealkent @ C Kent Araştırmaları Dergisi (Journal of Urban Studies) 
and appealing to society's upper and middle class. Taking such preventive measures globally and locally during the pandemic causes the pandemic to be experienced spatially and socio-economically on a class basis in daily practice. Therefore, this situation has caused the risk of infection to be seen more intensely in society's vulnerable and insecure segments.

Studies such as "Health for All," which provide important clues about the close relationship between urban planning, social justice, and epidemic diseases, have been carried out by the World Health Organization (WHO) regarding the problems that occurred. Another essential contribution in this regard is the " A health map for the local human habitat" study developed by Barton and Grant (2006). According to this map, wellness and health for individuals are part of a chain that complements each other as the global ecosystem, natural environment, built environment, activities, local economy, community, lifestyle, and people. Therefore, even if one of these dynamics is missing or biased, the state of being healthy becomes a social problem. Concerning this situation, the report titled "The Loss of Nature and the Rise of Pandemics," recently published by the Worldwide Fund for Nature (WWF), draws attention to the "links between the effects of humans on ecosystems and biodiversity and the spread of some diseases."

Contrary to all these studies, the continuation of capital-centered policies caused countries to not take precautions against the epidemic risk at the first stage and caused high death cases in metropolises during the pandemic process in the neoliberal period. Taking such preventive measures globally causes the pandemic to be experienced on a class basis, both spatially and socioeconomically, in daily practice during the pandemic process. Therefore, this situation has caused the risk of infection to appear more intensely in the vulnerable and insecure sections of society, both in the past and present pandemic experiences.

Along with modern and neoliberal urbanism, the gentrification of urban and public spaces and the effects of their construction following the material conditions of the capitalist and upper-middle-class segment became more observed intensely during the pandemic process. In particular, the capital-centered development of urban areas has limited the access of the urban poor to basic health services and public spaces during the pandemic period. This situation negatively affected the access to green areas, the right to good housing, access to health services, and social distance for the vulnerable groups 
of the city. As a result, this situation has caused the pandemic to be experienced on a class basis.

In this context, the same situation is distinctly observed in the Diyarbakır scale, and the uneven development of the pandemic process is in question. In addition, the fact that Diyarbakır, as a neoliberalizing city, is less discussed in the literature compared to other cities is the central dynamic that creates the importance and motivation of this study. Consequently, this study aims to analyze the effects of globally uneven development, spatial segregation, and neoliberal capitalism in the focus of the spatial organization of Diyarbakır through the experience of the covid-19 pandemic.

With this framework, the study aims to contribute to the urban studies literature, especially through the phenomena of class segregation and epidemic experience dynamics. While analyzing the relationship between the epidemic and the city, the Haussmann effect on modern urban planning, and the similarity of Le Corbusier's Radiant City project and the intensively built gated communities in Kayapinar will also be analyzed

\section{Kaynakça/References}

Bağlar Belediyesi. (2019). 2020-2024 Stratejik planı. 3 Kasım 2020 tarihinde http://www.sp.gov.tr/tr/stratejikplan/s/2193/Baglar+Belediyesi+_Diyarbakir+20202024 adresinden erişildi.

Barton, H. veGrant, M. (2006). A health map for the local human habitat. The Journal for the Royal Society for the Promotion of Health, 126 (6), 252-25.

BBC Türkiye. (2020 Nisan 23). Sokağa çkma yasağında çalışan işçiler: bizim sağlığımız önemli değil mi, biz ölmez miyiz? BBC Türkiye Servisi. 4 Kasım 2020 tarihinde https://www.bbc.com/turkce/haberlerturkiye52390109?at_custom3=BBC+Turkce\&at_ custom4=746B3D6A857A11EA9DFA8BAF923C408C\&at_campaign=64\&at_custom1 $=\% 5 B$ post+type\%5D\&at_custom2=twitter\&at_medium=custom7 adresinden erişildi.

Berg, R. V. (2020). How will covid-19 affect urban planning? The Cityfix. 10 Eylül 2020 tarihinde https://thecityfix.com/blog/will-covid-19-affect-urban-planning-rogier-van-den-berg/ adresinden erişildi.

Bozan, O. (2015). Diyarbakır vilayetinde 1894-1895 kolera salgını ve etkileri. Türk Dünyası Araştrmalan Dergisi, 218, 220-240.

Büyükcan, T. ve Yelken E. (2015). Şehir dışına göçeden okullar: eğitim kampüsleri. Eğitim Bilim Toplum, 13(49), 9-31.

Campbell, M. (2005). What tuberculosis did for modernism: the influence of a curative environment on modernist design and architecture. Medical History 49(4), 463-88. 
Campbell, M. (2005). What tuberculosis did for modernism: The influence of a curative environment on modernist design and architecture. Medhist 49(4) 463-488.

Castells, M. (2017). Kent sınıf iktidar (A. Türkün, Çev.). Ankara: Phoenix.

Chapman, B. (1953). Baron Haussmann and the planning of Paris. The Town Planning Review, 24(3), 177-192.

Corbusier, L. (1929). Contemporary city. from the. city of tommorrow and its planning içinde. New $\begin{array}{lllll}\text { York: } & \text { Dover } & 5 & \text { Ekim } & 2020\end{array}$ https://courses.washington.edu/gmforum/Readings/LeCorbusier.pdf adresinden erişildi.

Crompton, J. L. (2013). The health rationale for urban parks in the nineteenth century in the USA. World Leisure Journal 55(4), 333-346.

Çam, Y. (2020). Covid-19 süreci ve kentsel mekanların kullanımının yeniden planlanması. Osmaniye Korkut Ata Üniversitesi Ï̈BF Dergisi 4(2), 67-79.

D'Alessandro, D., Apolloni, L. ve Capasso, L. (2017). Public health and urban planing: a powerful allience to be enhanced in Italy. Ann Ig Journal, 29, 453-463.

Deverell, W. F. (2004). Whitewashed adobe: the rise of los angeles and the remaking of its mexican past, Berkeley: University Of California Press.

Diyarbakır Büyükşehir Belediyesi. (2006). Stratejik plan 2006-2009. 9 Kasım tarihinde http://www.sp.gov.tr/upload/xSPStratejikPlan/files/QazfU+DiyarbakirBuyuksehirSP0 609.pdf adresinden erişildi.

Durkin, E. (2020, 18 Mayıs). NYC's poorest neighborhoods have highest death rates from coronavirus. Poltico New York. 19 Temmuz 2020 tarihinde https:/www.politico.com/states/new-york/city-hall/story/2020/05/18/poorest-nycneighborhoods-have-highest-death-rates-from-coronavirus-1284519 adresinden erişildi.

Eker, G. (2020). The future of public spaces after pandemic: ghost spaces. UNDP. 20 Temmuz 2020 tarihinde https://www.tr.undp.org/content/turkey/en/home/blog/2020/05/ghostspaces-future.html adresinden erişildi.

Elbek, O. (2020). Türkiye'de değişen covid-19 stratejileri. Birikim Dergisi Güncel, 20 Haziran 2020 tarihinde https://birikimdergisi.com/guncel/10229/covid-19-stratejisi adresinden erişildi.

Engels, F. (2013). Konut sorunu (T. Genç, Çev.). Ankara: Alter Yayınları.

Enstitü İstanbul. (2021). Covid-19 pandemisinin İstanbul ekonomisine etkileri. 12 Mayıs tarihinde https://ipa.istanbul/yayin/covid-19-pandemisinin-istanbul-ekonomisine-etkileriraporu/ adresinden erişildi.

Enstitü İstanbul. (2020). "Yeni normal" süreci raporu: öngörüler, politikalar ve öneriler rehberi. 13 Mayıs tarihinde https://ipa.istanbul/yayin/yeni-normal-sureci-raporu-ongorulerpolitikalar-ve-oneriler-rehberi// adresinden erişildi.

Enstitü İstanbul. (2021). Salgında kent yoksulluğu: İstanbul'da yoksulluk profilleri.12 Mayıs tarihinde https:/ipa.istanbul/yayin/salginda-kent-yoksullugu-istanbulda-yoksulluk-profilleri/ adresinden erişildi. 
Ersoy, M. (2005). Türkiye'de kent planlamasının güncel sorunlanı. 9.Ulusal Halk Sağglğ̆ı Günleri Bildiri Özet Kitabr: Ankara.

Evrensel Gazetesi. (2020 Aralık 7). Vaka sayılarmın yükseldiği Adana'daki işçiler: bize öleceksen öl deniliyor. 12 Aralık 2020 https:/www.evrensel.net/haber/420522/vaka-sayilarininyukseldigi-adanadaki-isciler-bize-oleceksen-ol-deniliyor tarihinde adresinden erişildi.

Fitting, P. (2002). Urban planning/utopian dreaming: Le Corbusier's chandigarh today. Utopian Studies, 13(1), 69-93

Gambetti, Z. (2005). The conflictual (trans)formation of the public sphere in urban space: the case of Diyarbakır. New Perspectives On Turkey 32. 43-71.

Gandy, M. (2006). The bacteriological city and its discontents. Historical Geography, 34: 14-25.

Gehl People. (2020). Public space plays vital role in pandemic. 12 Ağustos 2020 tarihinde https:/gehlpeople.com/blog/public-space-plays-vital-role-in-pandemic adresinden erişildi.

Harvey, D. (1989). From managerialism to entrepreneurialism: the transformation in urban governance in late capitalism. Geografiska Annaler, Series B, Human Geography. 71, No.1., 3-17.

Harvey, D. (2003). New imperialism. New York: Oxford Press

Harvey, D. (2015). Sermayenin mekanlarn (S. Yüksel, Çev.). İstanbul: Sel Yayınları

Harvey, D. (2016). Kent Deneyimi (E. Soğanclar, Çev.). İstanbul: Sel Yayınları.

Heinrich Böll Stiftung Derneği. (2020). Pandemi döneminde derin yoksulluk ve haklara erişim $\begin{array}{llll}\text { arasstirmast. } & 22 & \text { Aralk } & \text { tarihinde }\end{array}$ https:/tr.boell.org/sites/default/files/202011/Pandemi\%20döneminde\%20derin\%20yo ksulluk\%20ve\%20haklara\%20erişim\%20araşttrmasıYerel\%20Yönetimlere\%20Kriz\%2 0Dönemi\%20Sosyal\%20Destek.pdf adresinden erişildi.

Hoffman, D. (2016). A crouching village: ebola and the empty gestures of quarantine in monrovia. City \& Society 28(2), 246-264.

Hutson, A., Kaplan, G. A., Ranjit, N., ve Mujahıd, M. S. (2012). Metropolitan fragmentation and health disparities: is there a link? Milbank Quarterly, 90(1), 187-207.

İçişleri Bakanlığı. (2021). 81 il valiliğine tam kapanma tedbirleri genelgesi. 7 Mayıs 2021 tarihinde https://www.icisleri.gov.tr/81-il-valiligine-tam-kapanma-tedbirleri-genelgesigonderildi adresinden erişildi.

Jacobs, J. (1961). The death and life great American cities. New York: Random House.

Johnson, S. (2007). The ghost map: the story of london's most terrifying epidemic-and how tt changed science, cities, and the modern world. New York: Riverhead.

Karacadağ Kalkınma Ajansı (2012). Şanlıurfa Diyarbakır kentsel alt bölge kalkınma yaklaşımı. 29 Ekim $2020 \quad$ tarihinde https:/www.karacadag.gov.tr/Dokuman/Dosya/www.karacadag.org.tr_162_BD8C6 6NE_sanliurfa_diyarbakir_kentsel_alt_bolge_kalkinma_yaklasimi.pdf adresinden erişildi.

Karacadağ Kalkınma Ajansı. (2014). TRC2 bölgesi yaşam kalitesi araştırması. 9 Aralık 2020 tarihinde https://www.karacadag.gov.tr/planlama/5/2/trc2-bolgesi-yasam-kalitesiarastirmasi/ adresinden erişildi. 
Karacadağ Kalkınma Ajansı. (2018). İstatistiklerle Diyarbakır. 9 Aralk 2020 tarihinde https://www.karacadag.gov.tr/Dokuman/Dosya/www.karacadag.gov.tr_307_WH5 M35SO_istatistiklerle_diyarbakir_2018.pdf adresinden erişildi.

Karadaş, E. (2020). Neoliberalizing Amed: gated communities in Diyarbakır 1999-2019. (Yüksek Lisans Tezi), İstanbul: İstanbul Bilgi Üniversitesi.

Kaygalak, S. (2008) Kapitalizmin taşrast: 16. yüzyldan 19. yüzyıla Bursa'da toplumsal süreçler ve mekânsal değişim. İstanbul: İletişim.

Keskinok, H. Ç. (2012). Kentlerde kamusal mekanların üretilmesi sorunu: bağlammn yitiren kentler, Mimarlk Dergisi, 364.

Keyder, C., ve Savran, S. (2013). İstanbul, küresel ile yerel arasmda. İstanbul: Metis.

Kıtay, M. S. (2002). Diyarbakır'da nüfus hareketlilikleri ve konut ihtiyactnın karşılanması için çözüm yöntemleri tartısması. (Yüksek Lisans Tezi) İstanbul: İstanbul Teknik Üniversitesi.

Kıygı, G. (2020). 19. yüzyılda salgın hastalıklar kentleri nasıl şekillendirdi? (II). Arkitera. 2 Eylül 2020 tarihinde https://www.arkitera.com/gorus/19-yuzyilda-salgin-hastaliklarkentleri-nasil-sekillendirdi-ii/ adresinden erişildi.

Kocabaş, A. (2020). Eşitsizlik ve covid-19; Türk Tabipler Birliği covid-19 pandemisi altnncı ay değerlendirme raporu içinde. 7 Ocak 2021 tarihinde https://www.ttb.org.tr/yayin_goster.php?Guid=42ee49a2-fb2d-11ea-abf2539a0e741e38 adresinden erişildi.

Koch, T. (2016). Cartographies of disease: maps, mapping, and medicine. California: Redlands.

Kulözü, N. (2016). Bir mekânsal modernleşme öyküsü: Erzurum kenti ve kentsel mekânında ikili dokunun oluşumu. İdealkent, 18, 22-47.

Kurtulus, H. (2008). (der.) Istanbul'da kentsel ayrışma. Istanbul: Bağlam.

Lefebvre, H. (2018). Şehir Hakkı (I. Ergüden Çev). İstanbul: Sel Yayınları.

Mcneil Jr., DG. (2014, 12 Ağustos). Using a tactic unseen in a century, countries cordon off ebolaracked areas. The New York Times. 5 Eylül 2020 tarihinde https:/www.nytimes.com/2014/08/13/science/using-a-tactic-unseen-in-a-centurycountries-cordon-off-ebola-racked-areas.html adresinden erişildi.

Mengirkaon, S. (2018). 19. yüzylın ikinci yarısında Diyarbekir'de veba-i bakari. İ.Özçoşar, A.Karakaş, M.Ziyatürk ve Z.Polat (Der), Osmanlı'dan Günümüze Diyarbakır içinde(295323). İstanbul:Ensar.

Nevius, J. (2020). New york's built environment was shaped by pandemics. Curbed NY. 20 Temmuz 2020 tarihinde https://ny.curbed.com/2020/3/19/21186665/coronavirus-newyork-public-housing-outbreak-history adresinden erişildi.

Odman, A. (2021, 20 Ocak). Pandemide çalışmakzorunda olmak: işçi sağlığı yoksa, halk sağlığı da yok. Sendikaorg. 2 Şubat 2021 tarihinde https://sendika.org/2021/01/pandemidecalismak-zorunda-olmak-isci-sagligi-yoksa-halk-sagligi-da-yok-606282/ adresinden erişildi.

Odman, A. ve M. Tülek (2020). Covid-19 pandemisi döneminde sosyo-mekansal eşitsizlikler ve veri/halkilişkisi. Covid-19 Pandemisi 6. Ay değerlendirmesiiçinde. 2 Eylül2020 tarihinde https:/www.ttb.org.tr/kutuphane/covid19-rapor_6/covid19-rapor_6_Part60.pdf adresinden erişildi. 
T.C Cumhurbaşkanlığı Strateji ve Bütçe Başkanlığı. (2019). on birinci kalkınma planı 2019-2023.14 Temmuz $2020 \quad$ tarihinde https://www.sbb.gov.tr/wpcontent/uploads/2019/07/OnbirinciKalkinmaPlani.pdf adresinden erişildi.

Özmen, B. (2018, Mart5). Ville Radieuse (Radiant City)/LeCorbusier. Arkitektüel.16Ocak 2021 tarihinde https:/www.arkitektuel.com/ville-radieuse/ adresinden erişildi.

Pala, K. (2018). Şehir hastaneleri: Türkiye'de sağlikta kamu-özel ortaklı̆̆. Istanbul: Iletișim.

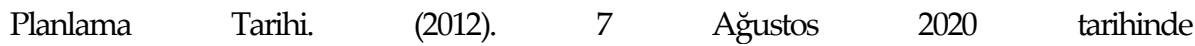
https://mrcngz.files.wordpress.com/2012/12/planlamatarihi.pdf adresinden erişildi

Przeworski, A. (2020, Haziran 10). Covid -19: magnificer of social mequality. Graduate Institute Geneva. 4 Ağustos 2020 tarihinde https://www.graduateinstitute.ch/coronavirusinformation-our-community-and-visitors/covid-19-magnifier-social-inequality adresinden erişildi.

Sassen, S. (1991) The global city: New York, London, Tokyo. Oxford: Princeton University.

Shah, N. (2010). Public health and the mapping Of chinatown, Asian American Studies Now: A Critical Reader içinde, J. Yu-Wen Shen Wu ve T. Chen (der). New Jersey : Rutgers University.

Snow, J. (1857). Cholera, and the water supply in the south districts of London. Bmj, S4-1(42), 864-865. doi:10.1136/bmj.s4-1.42.864

Şengül, T. (2009) Kentsel çelişki ve siyaset. Ankara: Imge Yayınevi.

T.C. Sağlık Bakanlığı.(2020). Covid-19 vaka haritası. 15 Ocak 2020 tarihinde https://hayatevesigar.saglik.gov.tr adresinden erişildi.

Tekeli İ. (2011). Türkiye'nin kent planlama ve kent araştırmaları tarihi yazıları. İstanbul: Tarih Vakfı Yurt Yayınları.

TTB. (2007). Kentler să̆llk hizmetlerinin örgütlenmesi: Çok sektörlü yaklaşım.18 Ağustos 2020 tarihinde

https://www.ttb.org.tr/kutuphane/kentlerde_saglik_hizmetleri.pdfadresinden erişildi.

TTB. (2020). Covid-19 Altıncı ay değerlendirme raporu. 14 Ocak 2021 tarihinde ttb.org.tr/kutuphane/covid19-rapor_6.pdf adresinden erişildi.

TTB. (2020). Covid-19 Dokuzuncu ay değerlendirme raporu. 16 Ocak 2021 tarihinde https:/www.ttb.org.tr/kollar/COVID19/yayin_goster.php?Guid=150a4bf4-49dd-11eb8d06-5bda367ed6b8 adresinden erişildi.

TUIK. (2019). Bölgesel İstatistikler.

TUIK. (2019). Sağ lık İstatistikleri.

TUIK. (2020). İlere göre ortalama hane halkı büyüklü̈̆̈̈, 2008-2020.

Türkiye Cumhuriyeti Sağlık Bakanlığı (2020). Covid-19 evde izlem önerileri. 13 Ağustos tarihinde https://covid19.saglik.gov.tr/Eklenti/38298/0/covid19evdeizlemonerileribrosra5pdf.pd f?_tag1=1FA4C8421F82618CB41695914044303720A4D096 adresinden erişildi.

UCLA. (2020). Covid-19 in vulnerable communities. 27 Ekim 2020 tarihinde https://latino.ucla.edu/research/covid-19-in-vulnerable-communities/ adresinden erişildi. 
Universus Sosyal Araştırmalar Merkezi. (2021). Evde kalamayanlar: Cơvid-19 günlerinde çalısma ilişkileri araştırması. 17 Mays 2021 tarihinde https://universus.org/2021/01/21/evdekalamayanlar/ adresinden erişildi.

Wilford, J.N. (2008, 15 Nisan). How epidemics helped shape the modern metropolis. The New York Times.26 Kasim 2020 https:/www.nytimes.com/2008/04/15/health/15iht15chol.11988148.html adresin erişildi.

WWF (2020). Doğanın yok oluşu ve pandemilerin yükselişi: insanlarm ve gezegenlerin sağhl̆ğm $\begin{array}{lllll}\text { korumak. } & 27 & \text { Ağustos } & 2020 & \text { tarihinde }\end{array}$ https://wwftr.awsassets.panda.org/downloads/doann_yok_olusu_ve_pandemilerin_ yukselii_25_04_20.pdf?9920/Doganin-Yok-Olusu-ve-Pandemilerin-Yukselisi adresinden erişildi.

Yıldırım, İ. (2020). Aile içi şiddetin ortaöğretim öğrencilerinin akademik başarnlan ile ilişkisi: Diyarbakur Bağlar örneği. (Doktora Tezi) Elâzı̆̆: Furat Üniversitesi.

Yıldırım, N. (2006). Su ile gelen ölüm: Kolera ve İstanbul suları. Toplumsal Tarih, 145, 2-11. 